Policy Research Working Paper 1823

Antidumping in Law Has the most recent and Practice

agreement curhed the

proliferation and misuse of antidumping torors? Not

quite.

Raj Krishna

The World Bank

Legal Department

Legal Reform and Advisory Services Division

September 1997 
POLICY RESEARCH WORKING PAPER 1823

\section{Summary findings}

The alarming increase in the number of antidumping actions pursued by both industrial and developing countries has caused considerable concern among economists, lawyers, and trade reformers. These concerns have led to suggestions to substitute antitrust principles for artidumping laws and regulations or to use safeguard measures under Article XIX of GATT 1994 and the Uruguay Round Agreement on Safeguards.

Krishna contends that, under current international trade law, neither proposal appears feasible. Moreover, antidumping actions have become a fact of life and the international community recognizes them as the only legitimate tool to combat dumping as defined by and determined in accordance with law.

Despite urgings in some quarters, neither national legal systerns nor international agreements have mandated an economy-wide cost-benefir analysis of proposed ancidumping actions. Because of political, technical, and other implications, such a methodology is unlikely to be accepred soon.

Although the most recent Uruguay Round antidumping agreement (URAA) has enhanced the discipline and made a number of improvements, it cannot claim to have plugged all loopholes for the misuse of antidumping. In those matters on which the agreement is silent or ambiguous or allows room for flexibility in adopting a rule, national authorities should adopt a less restrictive rule or practice.

A case in point is the U.S. practice on voting in the International Trade Commission. A 3-3 vote in antidumping and countervailing duty investigations constitutes an affirmative decision. It would be preferable to require a clear majority rather than treat an evenly divided vote as sufficient to establish a finding of injury.

This paper is a product of the Legal Reform and Advisory Services Division, Legal Department. Copies of the paper are available free from the World Bank, $1818 \mathrm{H}$ Street NW, Washington, DC 20433. Please contact Ana Maria Bobbio, room D6-053, telephone 202-458-1518, fax 202-522-1573, Internet address abobbio@worldbank.org. September 1997. (37 pages)

The Policy Research Working Paper Series disseminates the findings of work in progress to encourage the exchange of ideas about development issues. An objective of the series is to get the findings out quickly, even if the presentations are less than fully polished. The papers carry the names of the autliors and should be cited accordingly. The findings, interpretations, and conclusions expressed in this peper are entirly those of the authors. They do not necessarily represent the view of the World Bank, its Executive Directors, or the couniries they represent 


\title{
ANTIDUMPING IN LAW AND PRACTICE
}

\author{
RAJ KRISHNA
}





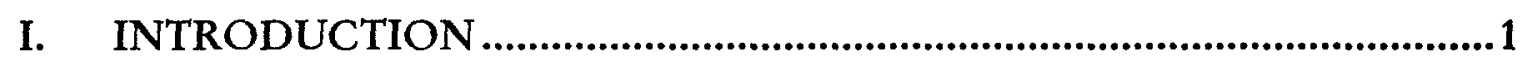

II. DUMPING: WHAT IT IS AND HOW IT OCCURS ...............................6

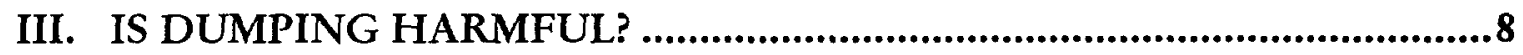

IV. MAJOR PROPOSALS................................................................................. 11

(a) Replace antidumping with antitrust principles .....................................................11

(b) Use safeguard measures under Article XIX GATT 1994 instead of ................ 12 $\mathrm{AD}$

(c) Antidumping duty should be a controlled remedy ........................................ 12

(d) Carry out "national economic interest" test or "nation-wide cost-benefit analysis" with respect to proposed AD action .................................................. 13

V. REMEDY AGAINST DUMPING: THE MUNICIPAL ANTIDUMPING

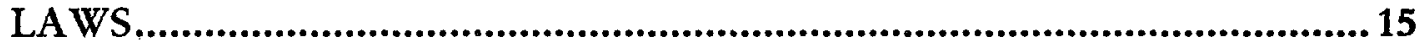

VI. ANTIDUMPING ON THE INTERNATIONAL PLANE AND VOICES

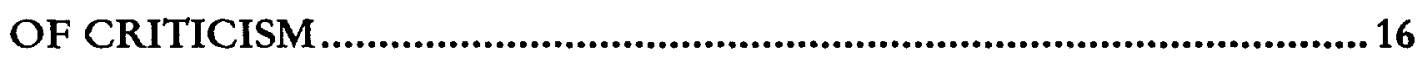

VII. URAA: THE NUTS AND BOLTS OF DUMPING ACTIONS ................. 18

1. Determination of Dumping ...................................................................... 18

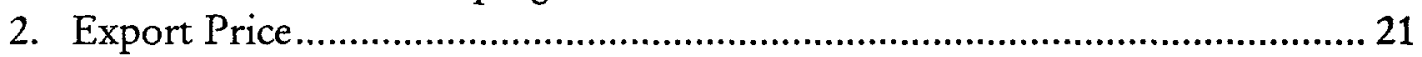

3. Adjustments............................................................................................. 21

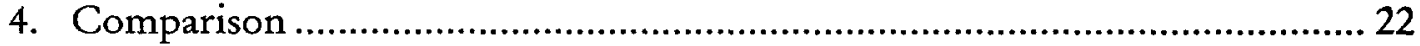

5. De Minimis Dumping Margin ................................................................ 22

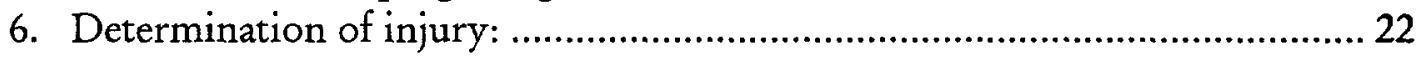

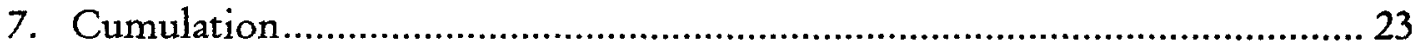

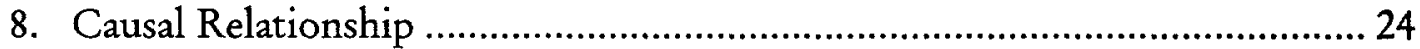

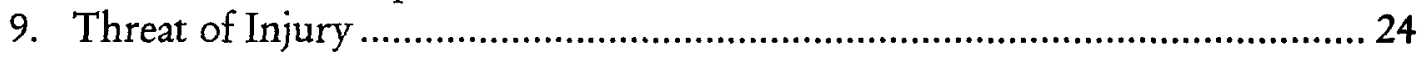

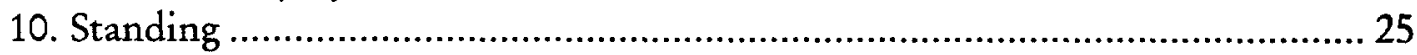

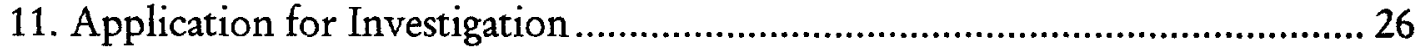

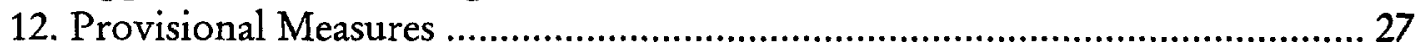

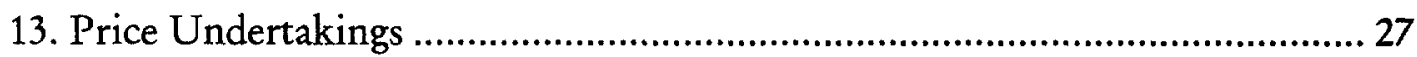

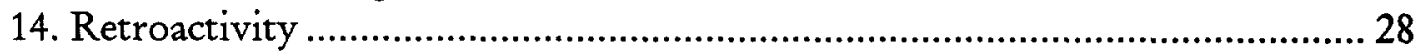

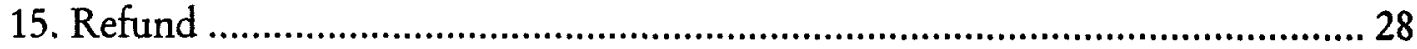

16. Imposition and Collection of Antidumping Duty ….................................. 29

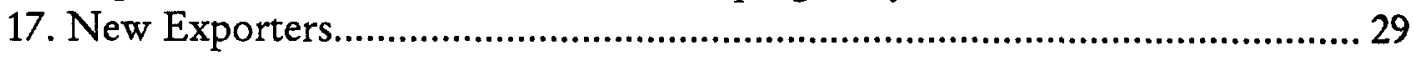

18. Duration Of Antidumping Duties And Undertakings ..................................30

19. Public Notice and Explanation of Determination ............................................ 30 


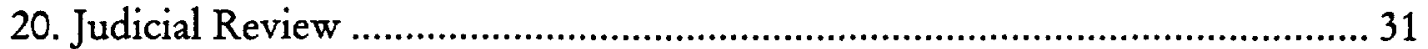

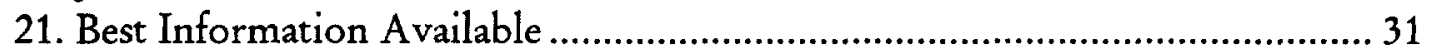

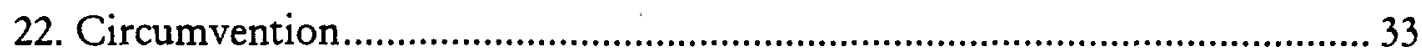

23. Anti-Dumping Committee ……................................................................. 33

24. Dispute Settlement...................................................................................... 34

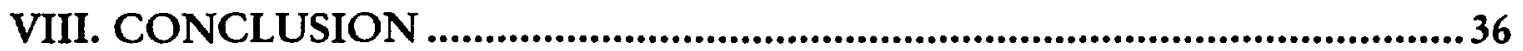




\title{
SOME ASPECTS OF ANTIDUMPING IN LAW AND PRACTICE
}

\author{
By Raj Krishna"
}

\section{INTRODUCTION}

In recent years antidumping (hereinafter sometimes "AD") has been catapulted to the forefront of the most controversial practices in international trade. While politicians scarcely hide their support for antidumping, there is little love lost between it and economists as well as trade reformers. Interestingly in World Bank's trade policy loans or loans in which trade policy reforms are a significant element, antidumping has generally not been a major issue either within the Bank or between the Bank and the borrowing Government. In most cases antidumping has been dealt with according to the exigencies of the situation. ${ }^{1}$ In view of the importance of antidumping to international trade and the fact that States do not appear to be too eager to renounce it in the near future, this paper discusses some significant issues involved and the changes introduced by the Uruguay Round of trade negotiations, with the hope that such discussion will be useful to policy and decision-makers in the international trade arena.

The last fifteen years have witnessed a phenomenal growth in the literature relating to dumping in international trade. The politicians, economists and lawyers have all participated in the ongoing debate on dumping with a zeal that is somewhat unprecedented even in respect of a trade issue. To a considerable extent the intensity of the debate is the direct outcome of the proliferation of antidumping laws and the increase in the incidence of the antidumping actions in the principal practitioners of this art among the developed countries and some developing countries who seem well set to catch up with the former. Although both Canada and U.S. have emerged as

\footnotetext{
Former Legal Advisor, International Trade, World Bank. The views expressed herein are those of the author and should not be attributed to the World Bank or its affiliates.

1 In a Trade Policy Loan to Venezuela (Loan No. 3092 VE), the enactment of antidumping and countervailing duty (hereinafter "CVD") legislation was specified as a condition for the release of the second tranche of the Loan see, Paragraph 3(b) of Schedule 1 and Paragraph 4 of Schedule 4, Loan Agreement (Trade Policy Loan) between Republic of Venezuela and the International Bank for Reconstruction and Development, dated October 16, 1989; for a Loan to Morocco (Loan No. 3463 MOR), the preparation for the regulations for implementation of the antidumping legislation was a condition for the presentation of the Loan to the Executive Directors of the Bank. Loan Agreement (Second Structural Adjustment Loan) between Kingdom of Morocco and International Bank for Reconstruction and Development, dated April 30, 1992. The Bank staff has played a useful role by offering technical and legal comments on proposed antidumping legislation of, among others, Cameroon, Costa Rica, Colombia, Senegal and Venezuela.
} 
major users of antidumping and countervailing against each other as well as against other countries including developing countries ${ }^{2}$ and the U.S. is regarded as the "world's leading prosecutor of unfair trade", Brazil, Korea and Mexico "have been rapidly attempting to turn the tables." ${ }^{3}$ According to the U.S. International Trade Commission (USITC) from 1980 through 1993, 682 antidumping and 358 CVD cases were filed in the United States. Of these, $39.4 \%$ of the antidumping and $21.2 \%$ of CVD cases resulted in affirmative final determinations and remedies ${ }^{4}$.

Antidumping and CVD investigations dramatically increased during the 1980 s. Boltuck and Litan show that between 1980-89, the number of antidumping investigations in the U.S. alone reached 451 and that of (CVD) to $301^{5}$ and that while

2 The formation of the North American Free Trade Area may have reduced but not eliminated antidumping and countervailing duty (hereinafter "CVD") actions between the parties. As recently as April 1996, Canada made a final determination of dumping against certain bacteriological culture media exported from the U.S. See, 13 International Trade Reporter (I.T.R.) 727 (1996). On the other hand, dumping investigations against laminated hardwood flooring from Canada are continuing in the U.S. Id. at 689. As far as Mexico is concerned, it recently took a decision to continue antidumping duty (hereinafter "ADD") first imposed in December 1991 against a U.S. exporter of concrete reinforcing bar. Canada has recently protested the imposition of ADD by Mexico on hot rolled steel exports from Canada to Mexico. The U.S. recently commenced antidumping investigations against fresh tomatoes from Mexico. These examples can be multiplied. As regards developing countries, between $1980-85$, about $12 \%$ of Argentinean exports to U.S. and $7.5 \%$ of those of Korea were under countervailing duties. See Nam, Chong-Hyun, "Export-Promoting Subsidies, Countervailing Threats, and the General Agreement on Tariffs and Trade," World Bank Eco. Rev. 727 at 736 (1986). Between 1980 and 1990, 28 antidumping actions were filed against Korean imports in the U.S.; of the cases resolved, $73 \%$ resulted in the affirmative and $27 \%$ in the negative determinations. Krupp, Cornine M., "A Shot Across the Bow: South Korea's First Test of it's Antidumping Law", 26 Journal of World Trade (J.W.T.), 111 at 114, note, (1992).

3 Boltuck, Richard and Robert E. Litan, "America's 'Unfair' Trade Laws" in Boltuck and Litan, Down in the Dumps, Administration of the Unfair Trade Laws, at 5 (Washington, D.C. 1991).

4 The Economic Effects of Antidumping and Countervailing Duty Orders and Suspension Agreements, USITC Publication 2900, June 1995, (hereinafter "Economic Effects") at 3-1.

5 Numbers of Antidumping and Countervailing Duty - Investigations in the U.S., 1980-89

\begin{tabular}{|l|l|l|} 
Year & AD & \multicolumn{1}{l}{ CVD } \\
\hline 1980 & 37 & 69 \\
\hline 1981 & 15 & 17 \\
\hline 1982 & 65 & 116 \\
\hline 1983 & 46 & 8 \\
\hline 1984 & 74 & 26 \\
\hline 1985 & 63 & 31 \\
\hline 1986 & 71 & 20 \\
\hline 1987 & 15 & 3 \\
\hline 1988 & 42 & 8 \\
\hline 1989 & 23 & 3 \\
\hline $\begin{array}{c}\text { TOTAL, } \\
1980-89\end{array}$ & 451 & 301 \\
\hline
\end{tabular}

Boltuck and Litan supra note 3, at 2. It may also be noted that in certain years, of all the CVD actions, those in Australia, Canada, Chile, New Zealand and U.S. accounted for $75 \%$ of all CVD initiatives, $76 \%$ of all provisional CVD, 92\% of all definitive CVDs. See Rugman, Alan M. and Samuel D. Porteous, "Canadian and U.S. Unfair Trade Laws: A Comparison of their Legal and Administrative Structures," 15 N. Carolina J. Int'l L. 67 at 82-83 (1990). 
the majority of investigations related to steel and lumber products even products of everyday use have not escaped such investigations. ${ }^{6}$ The table below shows that 1789 AD investigations were launched between 1980-89 in the U.S., EU, Australia and Canada. ' The number is much larger if investigations under various modalities of safeguard actions are taken into account.

6 Target Industries of U.S. AD and CVD Investigations, 1980-89

\begin{tabular}{lll}
\hline Industry & AD & CVD \\
\hline Chemicals & 58 & 37 \\
Food & 16 & 45 \\
Iron and Steel & 201 & 149 \\
Leather & $\ldots$ & 6 \\
Machinery & 8 & 6 \\
Nonferrous metals & 16 & 5 \\
Oil country trbular goods & 12 & 8 \\
Textiles and apparel & 15 & 6 \\
Lumber & $\ldots$ & 4 \\
Other & 125 & 34 \\
$\quad$ All products & 451 & 300 \\
\hline
\end{tabular}

7 See Messerlin, Patrick A., "Antidumping" in Schott, Jeffrey J. (Editor), Completing the Unuguay Round: A Results-Oriented Approach to the GATT Trade Negotiations at 110-11 (Washington, D.C. 1990). 
Number of Actions

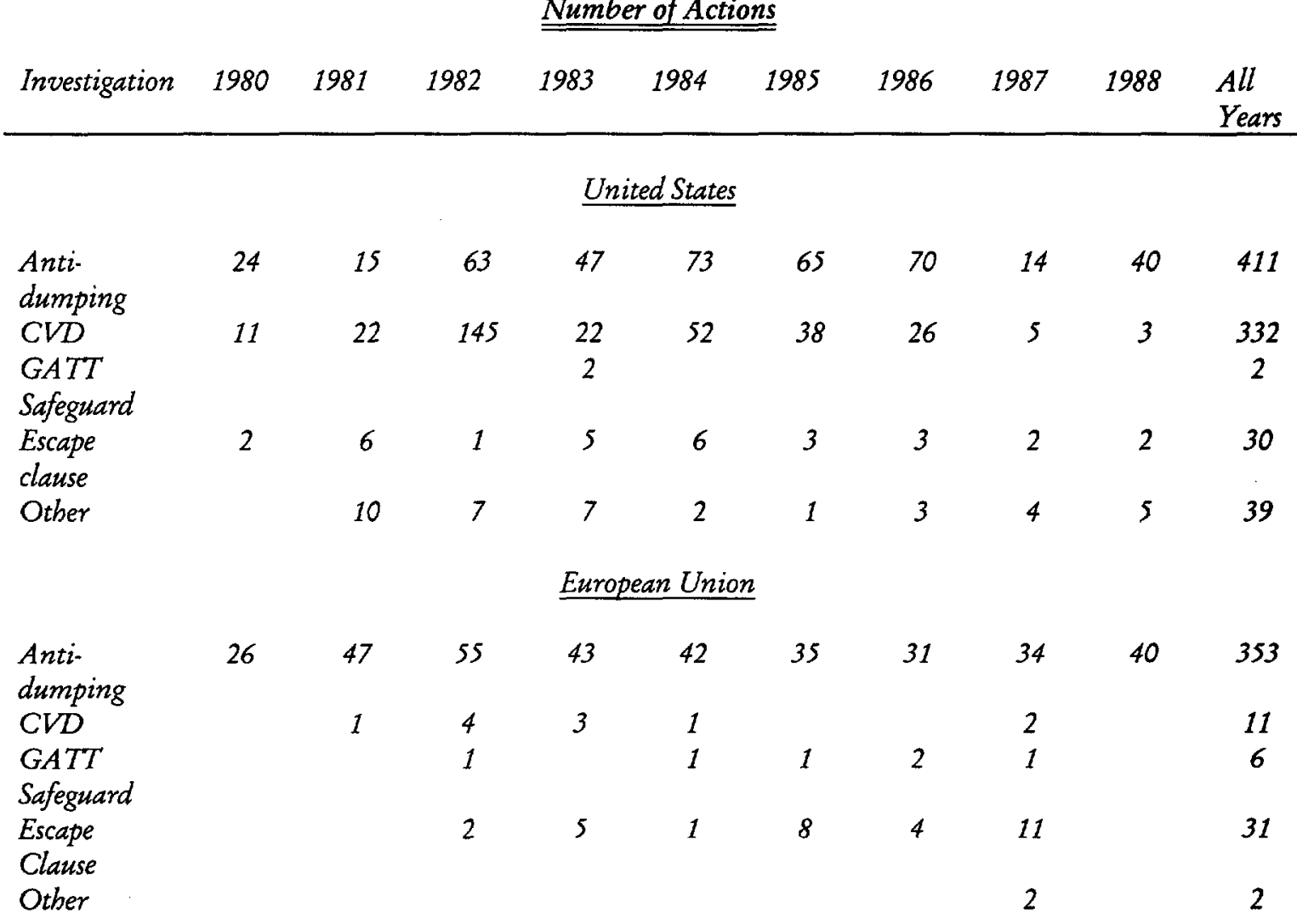

\section{Australia}

$\begin{array}{lllllllllll}\text { Anti. } & 58 & 49 & 77 & 80 & 56 & 63 & 62 & 17 & 16 & 478\end{array}$ dumping $C V D$ GATT Safeguard

Canada

$\begin{array}{lcccccccccc}\text { Anti- } & 25 & 23 & 72 & 36 & 31 & 36 & 85 & 86 & 53 & 447 \\ \text { dumping } & & & 1 & 3 & 2 & 2 & 4 & 6 & 2 & 23 \\ \text { CVD } & 3 & & 1 & & & & & & & 2 \\ \text { GATT } & & 1 & 1 & & & & & & \end{array}$

Developing Countries

Antidumping CVD GATT $\begin{array}{llll}5 & 23 & 47 & 75\end{array}$ Safeguard 
In the last two years, however, as reported to GATT/WTO, a downward trend in the antidumping actions taken globally is discernible. During the period July 1 , 1993 - June 30, 1994 the total number of antidumping investigations reached 222, two less than the previous corresponding period. The initiation of actions reported was: EU (47), U.S. (47), Australia (45), Brazil (30), Mexico (23), Canada (22), New Zealand (2), India (1), Japan (1) and Korea (4). During the period July 1, 1994-June 30, 1995, the total number of antidumping investigations declined further. Of the 142 investigations initiated during this period, Argentina reported (6), Australia (6), Brazil (12), Canada (9), Colombia (1), EU (37), India (9), Korea (3), Mexico (18), New Zealand (9), Singapore (2), and the U.S. (30). By June 1995, the total number of measures in force was 724 of which the U.S. accounted for (305), EU (178), Canada (91), Australia (86) and Mexico (42). ${ }^{8}$

With the increase in its pending investigations, Mexico has now earned the dubious distinction of having the greatest antidumping caseload in the world. ${ }^{9}$ A recent entrant into this field is India and China is likely to follow soon. Along with trade liberalization measures of the early 90 s, India energized its antidumping procedures which had been lying dormant in the statute book for about a decade. ${ }^{10}$ By January 1995, one final determination of dumping had been made and ADD imposed $^{11}$, one provisional antidumping ADD imposed ${ }^{12}$ and six investigations were in the pipeline. ${ }^{13}$ From 1993 through July 1996 about 40 complaints are said to have been received ${ }^{14}$. Another new user of antidumping is Thailand. Two investigations have been carried out so far with one resulting in the imposition of antidumping duty against India. The spread of antidumping actions to developing countries was anticipated and should not come as a shock or surprise. ${ }^{15}$

While the number of countries resorting to antidumping weaponry has increased, the overall growth rate of $\mathrm{AD}$ actions, as pointed out earlier, appears to be

\footnotetext{
8 WTO, GATT Activities 1994-1995, at 77-78 (Geneva, April 1996).

$9 \quad 12$ I.T.R. at 564 (1995).

10 Antidumping provisions were inserted in the Customs Tariff Act, 1975 in 1982. See also Customs Tariff (Identification, Assessment and Collection of Anti-Dumping Duty on Dumped Articles and for Determination of Injury) Rules, 1995 promulgated after the Uruguay Round replacing the erstwhile Customs Tariff (Identification, Assessment and Collection of Duty or Additional Duty on Dumped Articles and for Determination of Injury Rules, 1985. The need for antidumping measures was emphasized in Business Times of India, April 7, 1992.

11 Poly Vinyl Chloride Resin from Argentina, Brazil, Mexico, Republic of Korea and USA. Ministry of Commerce Notification, July 30, 1993. The Gazette of India: Extraordinary Part I - Sec 1.

12 Bisphenol-A from Japan. Ministry of Commerce Notification, August 10, 1993, The Gazette of India Extraordinary, Part I - Sec. 1.

${ }^{13}$ Acrylonitrite Butadine Rubber from Japan; Potassium Permanganate from China; Bisphenol " $A$ " from Russia and Brazil; 3,4,5 - Trimethoxy Bezaldehyde from PR China; Theophylline and Caffeine from P.R. China; and Isobutyl benzene from China.

14 India Abroad, New York, at 26 (July 19, 1996).

15 Thus Boltuck and Litan observed that the U.S. technology of identifying "unfair trade" has reached abroad and that the U.S. will reap the consequences. Boltuck and Litan, supra note 3 , at 6 .
} 
slowing down for the principal users. This may very well be the result of the enhanced discipline introduced by the Uruguay Round of trade negotiations ${ }^{16}$

Antidumping actions have often proved to be dilatory and cumbersome. At times more than 25 companies have been subject to investigations. ${ }^{17}$ The filing of 72 trade cases against 20 countries by the U.S. steel producers in 1992 and the subsequent imposition of preliminary ADD and CVD "provoked outrage in the world steel community." ${ }^{18}$ The U.S. Department of Commerce ruled that steel products from 19 countries were being dumped in the U.S. ${ }^{19}$

\section{DUMPING: WHAT IT IS AND HOW IT OCCURS}

Dumping is defined variously in the literature on the subject. Central to all these definitions, however, is the concept of price discrimination in different markets. Thus, in 1922, Jacob Viner defined dumping as "price discrimination between national markets. ${ }^{~} 20$ In international trade dumping is said to occur when the sale of products for export is at "prices lower than those charged to domestic buyers, taking into account the conditions and terms of sale." ${ }^{21}$ According to other writers: "Loosely defined, dumping occurs when similar products are sold by a firm in an export market for less than what is charged in the home market. Alternatively it may occur if the export price of the product is less than total average costs or marginal costs."22 According to Article VI, GATT 1994, a product is said to be dumped when its export price is less than its normal value, that is, less than the sale of a like product in the domestic market. The concept appears to be simple enough. But the determination of the export and the home-market prices and their comparison have proven to be anything but simple in State practice.

Economists have debated whether, and if so, under what circumstances does dumping take place. Jacob Viner identifies three types of dumping situations: sporadic

16 Thus in January 1995, the number of pending AD and CVD actions in the U.S. stood at 19 and 4, respectively, 12 I.T.R. 191-193 (1995) and in January 1996, at 9 and 1, respectively, see 13 I.T.R. 178-179 (1996). By April 1996, the number of pending actions did show an increase. Id. at 690-691.

17 Certain Antifriction Bearings 54 Fed. Reg. at 20900-12 (1989).

18 Oxford Analytica, June 17, 1993.

19 See 10 I.T.R.at 1014 (1993).

20 Viner, Jacob, Dumping: A Problem in International Trade, at 3 (Chicago, 1923).

21 Slayton, P., "The Canadian Legal Response to Steel Dumping" Canada U.S. Law In'l 1979 quoted in Lazar, F., "Antidumping Rules following Canada - United States Free Trade Agreement." 23 J.W.T. 45 (1989).

22 Hoekman, Bernard M. and Michael P. Leidy, "Dumping, Antidumping and Emergency Protection", 23 J.W.T. 27 (1989, No. 5). James Devault says: "The phenomenon of dumping takes place when a firm sells a product abroad at a price which is beneath its fair value." See Devault, "The Administration of US Antidumping Duties: Same Empirical Observations." 13 World Economy, 75, (1990). For a rather elusive definition, see Finger, J. Michael, Editor, Antidumping How It Works and Who Gets Hurt, (Ann Arbor, University of Michigan Press, 1993), wherein the following definition is given: "The pragmatic definition of dumping is the following: dumping is whatever you can get the government to act against under the antidumping law." at viii. 
dumping, short-run or intermittent dumping and long-term or continuous dumping. In the case of sporadic dumping the motivation is to dispose of goods for a short-run to get rid of surplus shock. Short-run or intermittent dumping is not continuous and is motivated by entering into a new market, retaining the market share or driving away the competitors from the market. Long-term or continuous dumping is motivated by the intent to reach or maintain full production in large scale economies. Sporadic dumping is likely to result only in damage to the exporting or the importing country. Short-run dumping also does not necessarily hurt. ${ }^{23}$

Viner argued that $\mathrm{AD}$ authority may be needed to protect domestic consumers against predatory dumping. In predatory pricing a foreign firm or cartel attempts to drive away the domestic competitors then establishes a monopoly and subsequently increases the price. ${ }^{24}$ "Predatory Pricing", thus, "refers to the use of short-run price cutting in an effort to exclude rivals on a basis other than efficiency in order to gain or protect market power. . . Predatory pricing, however, is a complex form of anticompetitive conduct. It requires the perpetrator to incur substantial losses or at least to forego present profits in the hope that those losses can be more than recouped in the future through the exercise of market power. Thus, market conditions play a key role in determining whether price predation is a feasible tactic for a firm to employ. The predator must have a very substantial share of the market or at least the capacity to acquire such a share." ${ }^{25}$

However, economists are not in full agreement as to the occurrence of predatory dumping. It is maintained that it is inconceivable for a firm to suffer losses over a long period of time and that as for predatory dumping a firm must establish a global monopoly, that too is difficult to conceive will happen in most industries. Hoekman and Leidy point out that even laboratory experimental work by Isac and Smith has failed to produce any evidence of predatory pricing. ${ }^{26}$

On the other hand it is maintained by others that instances of predatory pricing are there although they are rare. Thus the OECD Report mentioned above concludes: "Perhaps all that can be said is that cases of predation may arise but at most only very rarely." 27 Much in the same vein, Hindley observes that examples of predatory pricing are few, "they are not zero." According to him, recent analysis that suggests predatory pricing will "never" occur is too strong. He goes on to say: "The law and economics

23 Beirwagen, Rainer M. and Kay Hailbronner, "Input, Downstream, Upstream, Secondary, Diversionary and Components or Subassembly Dumping", 22 J.W.T. 27 at 32 note 27, (No. 3 1988). See also, Schoenbaum, Thomas J., "Antidumping and Countervailing Duties and the GATT: An Evaluation and Proposal for a Unified Remedy for Unfair International Trade", 30 German Y.B.I.L. 177 at 179 (1987).

${ }_{24}$ Viner attributes the enactment of the first antidumping provision in the U.S. in 1916 to the dumping threat posed by the highly cartelized and heavily protected German industries. See Staiger, Robert W. and Frank A. Wolak, The Effect of Domestic Antidumping Law in the Presence of Foreign Monopoly, NBER Working Paper Series, Working Paper 3254 at 1 (February 1990).

25 OECD, Predatory Pricing, at 81 (Paris, 1989).

26 See Isaac, R. Mark and Vernon L. Smith, "In Search of Predatory Pricing" 93 J. Pol. Eco. 320 (1985) referred to in Hoekman and Leidy, supra note 22, at 32.

27 OECD, supra note 25 , at 81 . 
of predatory pricing, in fact, is something of a swamp. Fortunately, it is not necessary to enter that swamp to discuss contemporary antidumping policy. The simple fact is that the great bulk of actual antidumping cases cannot conceivably be explained in terms of predatory pricing." ${ }^{28}$

In order for the dumping to take place, it is maintained that: (i) markets must be segmented so that exporters' home market is sealed against secondary sales, (ii) exporting firm acquires sufficient market power in at least one market to enable it to influence the price, and (iii) export market demand is more elastic than in the home market, i.e. the sales are responsive to lower price. ${ }^{29}$ A question then arises whether such segmentation is possible in international market. In this connection it is pointed out:

"However, in practice, market segmentation will usually be the primary necessary condition for price dumping to occur. The question then arises: is international market segmentation common? For many products and industries the answer is yes. Product differentiation, variation in tastes, trade policies and regulatory regimes, differing product standards, etc., all work to segment markets. The result is that the trading environment will often be quite conducive to acts of intentional and unintentional price dumping."30

To some who doubt that dumping at all takes place, the following remarks of the authors may be drawn to their attention:

"The dual definition of dumping (i.e. price dumping and cost dumping), the possibility of deliberate and unintentional dumping, and the relatively weak conditions necessary to produce an environment hospitable to both types of dumping, all suggest that its occurrence as defined by law will be frequent." 31

\section{IS DUMPING HARMFUL?}

There is no hard and fast answer from economists to the question whether dumping is detrimental. ${ }^{32}$ It is quite obvious, though, that the consumers of dumped product gain while the producers of the like product may suffer a loss. Antidumping is, therefore, viewed as having no economic justification. Hindley says:

28 Hindley, Brian, "The Economics of Dumping and Anti-Dumping Action: Is there a baby in the bath water?" in Tharakan, P.K.M., Ed., Policy Implications of Antidumping Measures, 25 at 29 (Elsevier Science Publishers B.V., Amsterdam 1991).

29 Hoekman and Leidy, supra note 22 , at 30-31.

30 Id. at 31

31 Id. at 32 .

32 Beirwagen and Hailbronner, supra note 23, at 33. 
"The problem for antidumping policy is to explain why the mere fact that the dumping firm charges a higher price in its home market is sufficient to provide competing domestic firms (or their government) with a right to take action against the dumping - with a right to require or compel such a higher price in their own market." ${ }^{33}$

Some economists have argued that before the national authorities impose antidumping duty, a study of the entire economy-wide effects of such imposition must be studied. $^{34}$ Studies of this nature are non-existent. The Economic Effects, mentioned earlier, is only an ex post facto analysis carried out by USITC of "the economy-wide effects of a simultaneous removal of outstanding AD/CVD orders in 1991". According to this analysis the removal results in a welfare gain to the U.S. economy of $\$ 1.9$ billion. Had the effect of approximately another 110 orders since 1991 been taken into account the net gain to the economy likely would have been "far greater". ${ }^{35}$

As against the views which deny examples of cases in which antidumping action is economically justified, one could refer to what the U.S. Assistant Attorney-General Samuel Graham stated in 1916. He observed:

"... generally accepted principles of political economy hold that it is not sound policy for any Government to permit the sale in its country by foreign citizens of material at a price below the cost of production at the place produced, for the reason that such a system, in its final analysis and on a sufficient scale, spells bankruptcy." 36

Even if bankruptcy is viewed as a rather far-fetched consequence, it is recognized that for an importing country short-term benefit to consumers buying dumped products may conflict with the long-term national economic interests. ${ }^{37}$

Dumping is considered to provide an unfair trade advantage to the exporter and therefore contrary to the cannons of free trade. A recent writer has observed that many statesmen, scholars and trade specialists recognize that free trade and fair trade go hand in hand. ${ }^{38}$ Some writers, however, regard the legalism of distinguishing between

33 Hindley, supra note 28 , at 30 .

34 This aspect is discussed later in this paper. See pp. 13-15 infra.

35 See supra note 4 , at $x$-xi, III.

36 Quoted in Stewart, Terence P., Editor, The GATT Uruguay Round, A Negotiating History (1986-1992), Vol. Il at 1390 (Kluwer, Deventer, 1993).

${ }^{37}$ See Eckes, Alfred E., "The Interface of Antitrust and Trade Laws - Conflict or Harmony? An ITC Commissioner's Perspective," 56 Antitrust L.J. 417 (1987).

38 See Piontek, Eugeniusz, "Anti-Dumping in the EEC - Some Observations by an Outsider," 21 J.W.T.L. 67 at 68 (August 1987). The concern with "fair" trade was expressed by President Reagan in these words: "To make the international trading system work, all must abide by the rules - all must work to guarantee open markets. Above all else, free trade is, by definition, fair trade. When domestic markets are closed to the exports of others, it is no longer free trade. When governments subsidize their manufacturers and farmers so that they can dump goods in other markets, it is no longer free trade. When governments permit 
unfair and fair trade as by itself a non-tariff barrier; while some others do not regard such distinction as important. A typical observation may be noted:

"There is nothing self-evidently fair about the displacement of domestic miners as an outcome of the discovery abroad of cheaplymined coal, or in a competition between domestic textile workers and unsubsidized foreign workers earning a fraction of the domestic trade ... It follows that the adoption of a special course of action to deal with unfair competition is likely to weaken the foundations upon which policies with respect to fair competition are based." 39

To some the right to retaliate against dumping is not founded in unfairness but in the excessive cost of market disruption as much by "unfair" trade as by "fair" trade. Thus, why imports are cheap is irrelevant. ${ }^{40}$ It has also been suggested that instead of drawing the distinction of "fair" and "unfair" trade, one should focus on "acceptable vs. unacceptable levels of trade or market share or import penetration, however, the concept is formulated. So long as we are not willing to legislate world-wide uniformity in wage scales, exchange rates, environmental controls, debt/equity ratios, depreciation, interest rates, and accounting techniques, and indeed comparable relations between government and industry, what is fair and what is unfair is in large part coincidence." 41

Be this as it may, it is correct to say that by and large $\mathrm{AD}$ measures have gone beyond creating a level playing field and have been used to protect declining industries. $^{42}$ Dale concludes that "[a]ntidumping laws are at best superfluous and at worst a serious impediment to commerce." 43 These strong views stem from criticisms both of the theoretical bases of antidumping policies and the implementation of those

\footnotetext{
Continued

counterfeiting or copying of American products, it is stealing our future, and it is no longer free trade... When governments assist their exporters in ways that violate international laws, then the playing field is no longer level - and there is no longer free trade. When governments subsidize industries for commercial advantage and underwrite costs, placing an unfair burden on competitors, that is not free trade. . I believe that if trade is not fair for all, then trade is 'free' in name only." Quoted in Snape, Richard H., "The Importance of Frontier Barriers" in Kierzkowski, Henryk, Editor, Protection and Competition in International Trade: Essays in Honor of W.M. Corden 215 at 228-29 (London, 1987).

39 Hindley, Brian, "Subsidies, Politics and Economics" in Wallace, Don, Frank J. Loftus and Van Z. Krikorian, Editors, Interface Three: Legal Treatment of Domestic Subsidies 29 at 30-31 (Washington D.C. at 1984), hereinafter referred to as "Wallace".

${ }_{40}$ Barceló III, John J., "Subsidies, Countervailing Duties and Antidumping After the Tokyo Round." 13 Cornell Int'l L.J. 257 at 260 (1980). See also same writer, "An 'Injury-Only' Regime (For Imports) and Actionable Subsidies" in Wallace, supra note 39, at 19.

41 Lowenfeld, Andreas F., "Fair or Unfair Trade: Does It Matter" 13 Cornell Int'l L.J. 205 at 219 (1980).

42 Wilkinson, Bruce W., "The Saskatchewan Potash Industry and the 1987 U.S. Antidumping Action", 15 Can. Pub. Policy 145 (1989).

43 Dale, R., Anti-dumping Law in a Liberal Trade Order (Macmillan, London), 1980 quoted in Yarrow, George "Economic Aspects of Anti-Dumping Policies," 3 Oxf. Rev. of Ec. Pol. 66 at 66-67 (1987).
} 
policies. ${ }^{44}$ Antidumping laws, it is maintained, are biased in favor of finding of dumping. ${ }^{45}$

Finding little or, at best, dubious justification for antidumping, some writers have suggested other alternatives as well as more rigorous methodological and other changes. The more significant ones are discussed below under "Major Proposals". Some changes proposed from time to time as regards specific aspects of antidumping laws and practices did find acceptance at the Uruguay Round and the same are noted in the discussion relating to URAA. ${ }^{46}$

\section{MAJOR PROPOSALS}

\section{(a) Replace antidumping with antitrust principles ${ }^{47}$}

The replacement of $\mathrm{AD}$ laws by antitrust principles has been proposed particularly in the context of NAFTA. The official U.S. view, however, is that the $\mathrm{AD}$ and CVD laws "are likely to remain as 'basic components' of American trade law for some time because of the intermediating function they play between different styles of market economies. The U.S. antidumping and countervailing duty laws will not be on the table in the foreseeable future. ${ }^{.48}$ It should be noted that not only the antitrust and $\mathrm{AD}$ laws, as for example in the U.S., have fundamentally different policy objectives, they also have major substantive and procedural differences. With such differences, it is felt, that "it remains likely, if not inevitable, that the application and enforcement of the antidumping law and the antitrust laws will continue to be generally inconsistent and often in conflict with one another." ${ }^{49}$

44 Id.

45 See, generally, Jackson, John H. and Edwin A. Vermulst, Antidumping Law and Practice, A Comparative Study (University of Michigan Press, Ann Arbor), 1989. For a critical evaluation of U.S. antidumping practice, see Schoenbaum, supra note 23, at 177 et seq. A Japanese report alleged that the U.S. was moving towards an "illegitimate mechanism operating outside the international rules." Financial Times, July 17, 1991, at 8.

As regards EU Norall points out: "In a word, if certain facts are present, various aspects of the technical methodology now applied by the Commission in anti-dumping cases tends to make findings of dumping at significant levels automatic and inevitable. .." See Norall, "New Trends in Anti-dumping Practice in Brussels", 9 World Economy 97, at 98 (1986). A small minority of writers feels that U.S. law is not being administered in a "blatantly" protectionist manner nor does such law has a protectionist bias. On this, see Devault, supra note 22 , at 75 et seq.

46 Agreement on Implementation of Article VI of the General Agreement on Tariffs and Trade 1994. For the text of URAA see, Office of the United States Trade Representative, Uruguay Round, Final Texts of the GATT Uruguay Round Agreements Including The Agreement Establishing the World Trade Organization, As Signed on April 15, 1994, Marrakech, Morocco (Washington D.C.) at 145-169.

See comments of Calvin Goldman of Davies Ward \& Beck of Toronto, 13 I.T.R. 255 (1996).

48 12 I.T.R. 1393 (1995).

49 Applebaum, Harvey M. and David R. Grace, "U.S. Antitrust Law and Antidumping Actions Under Title VII of the Trade Agreements Act by 1979," 56 Antitrust Law Jn'l, 497 at 518 (1987). 
Another related suggestion is that antitrust authorities should participate in $A D$ cases with the power to veto actions deemed likely to be harmful to competition. ${ }^{50}$ Given the differences between the thrust and the objectives of the $A D$ and antitrust laws, it is doubtful if such a veto power can be given to antitrust officials. It may be noted that in the 1970 s the antitrust division of the Justice Department of the U.S. used to participate in the $\mathrm{AD}$ proceedings but the practice was later discontinued as it proved quite unsuccessful.

\section{(b) Use safeguard measures under Article XIX GATT 1994 instead of AD}

Prior to the conclusion of the Uruguay Round certain writers made proposals in this direction. ${ }^{51}$ The limitations of space do not permit a full discussion of GATT "safeguard" clause and its alleged superiority over antidumping actions or of the legality of the recourse to the use of such clause in the normal course to counteract dumping. Suffice it to say that Article XIX (safeguard) and Article VI (antidumping) of GATT 1994, together with their complementary Uruguay Round agreements are designed for different situations. The former afford protection when the domestic industry suffers injury by a sudden surge in imports in fair trade and where no allegations of wrong-doing are made while the latter provide remedy against unfair trade. There can be circumstances where the two overlap as, for example, when the sudden increase is attributed to dumping; in that case one could perhaps resort to safeguard clause. It is difficult to see how in most cases the importing country can resort to Article XIX and the Uruguay Round Agreement on Safeguards (URSA) to remedy $\mathrm{AD}$.

\section{(c) Antidumping duty sbould be a controlled remedy}

It has been proposed that the $A D D$ could be decreased by a fixed proportion per year ${ }^{52}$ or that the $A D$ law cap the amount of $A D D$ so that the tariff, if any, together with the ADD shall not exceed a certain amount. Both suggestions are interesting. But any a priori specification of a percentage by which the ADD should taper off yearly or of a ceiling could frustrate the purpose of ADD which is to offset the dumping margin. It will be appreciated that dumping margins have often been determined to exceed $100 \%{ }^{53}$ There is also a risk that the tapering off of or the capping

so Hoekman and Leidy, supra note 22, at 41.

51 Barceló III advocated a single safeguard code "as the sole standard for relief against all injurious imports". See Barceló III, "Subsidies, Countervailing Duties and Antidumping After the Tokyo Round", supra note 40, at 258. Other writers like Gary Sampson and Finger also support recourse to Article XIX GATT 1994 rather than to Article VI.

52 Hoekman and Leidy, supra note 22, at 41.

53 See, for example, U.S. Department of Commerce's (hereinafter "Commerce") determinations in Coumarin from the People's Republic of China, USITC Pub. 2852, February 1995, (160.8\%) at A-14; Fresh Garlic from the People's Republic of China, USITC Pub. 2825, November 1994 (376.67\% BIA (i.e. best information available) rate as alleged in the petition) at A-11. In a case brought by Eastman Kodak against Fuji Photo Film Co., Commerce, in a preliminary determination, slapped margins of dumping of 
of ADD could lead to increased dumping or to exports with greater dumping margin inasmuch as the exporters would be aware of the limitations of the importing country to retaliate.

\section{(d) Carry out "national economic interest" test or "nation-wide cost-benefit analysis" with respect to proposed $A D$ action}

According to the proponents of this view, the $\mathrm{AD}$ mechanism must provide an economy-wide assessment of the effects of the $A D$ measure. The advisability of adopting this test is strongly advocated by Hoekman and Leidy in these words:

"Incorporation of a national interest clause in AD procedures would be a major improvement. It would imply that before an affirmative finding can be made, a cost/benefit analysis should indicate that for the nation as a whole protection of an industry is worthwhile. A weaker version of this idea would be to allow consumer interests to have a greater voice in $\mathrm{AD}$ proceedings than is presently the case. If it were required that all users of the products (both final consumers, if any, and firms using the affected products as inputs) be offered a voice, the likelihood of affirmative actions might diminish." ${ }^{54}$

The central element of the national economic interest test is "to change the focus of the investigation from the effect of the proposed restriction on domestic producers of like or competing goods to the effect on the national economic interest of the restricting country." By national economic interest is meant "the sum of the benefits to all nationals who benefit minus the costs to all nationals who lose. Injury, as it is defined in trade remedy law, is one half of the national economic interest (... usually the smaller half)." ${ }^{55}$

To a lawyer such proposals ring a familiar bell as they are reminiscent of the ideas of the English utilitarians of the 18th century to whom the test of good legislation was "the greatest happiness of the greatest number." As Jeremy Bentham's

Continued

$321 \%$ to $360 \%$ on the photographic paper. See, 11 I.T.R. at 1181-82 (1994). A margin of as high as $595.66 \%$ was found in respect of Venezuela, see, Carbon Steel Butt-Weld Pipe Fittings from France, India, Israel, Malaysia, Korea, Thailand, United Kingdom and Venezuela (Inv. Nos. 731-TA-688-695), 59 FR 50560 October 4,1994 . It is interesting to note, however, that even a high dumping margin may not necessarily result in a positive injury finding. See for such a situation, Saccharin from China and Korea (Inv. Nos. 731-TA-675, 676), 11 I.T.R. at 1985 (1994).

54 See, Hoekman and Leidy, supra note 22 at 41 . See also Yarrow, supra note 43 at 77 , who, while recommending cost-benefit analysis, also recognizes that the value of such analysis could be doubted as there is little reason to believe that the impact of dumping on welfare will generally be negative.

55 Finger, supra note 22 , at 70 . Under this approach, the "injury investigation" will be replaced by a national economic interest investigation which will not be "retrofitted to antidumping cases" as at present. Id. at 71 . 
hedonistic calculus ${ }^{56}$ would involve aggregating the pleasures on one side and pains on the other so would the proposed cost-benefit analysis for the "nation as a whole" which, perhaps, is easily said than done. What factors will go into such analysis? What weight shall be given to pain and suffering and lost expectations of those affected by allowing an industry to perish? In this regard the observations of a lawyer, although a staunch defender of U.S. AD laws and practice, deserve to be quoted. Stewart asserts:

"The American landscape is littered with the tombstones of companies starved by inadequate returns of capital employed. Many such tombstones have nothing to do with artificial advantages used by foreign competitors. Many -too many- are the direct result of dumping into the U.S. market." ${ }^{57}$

Since a cost-benefit analysis for the nation as a whole would not be based exclusively on econometrical equations but also on some objective criteria the possibility of legal challenges in a court of law cannot be ruled out. Writers proposing this test unfortunately do not throw sufficient light on the methodology to be followed. $^{58}$

It is submitted that not only would such an analysis be itself costly and timeconsuming, it will likely be politically unacceptable as well. The reason is not far to seek. When a State causes injury to its citizen or citizens in the larger interest of the public (e.g. the exercise of the power of eminent domain) it has to follow due process of law and must compensate those who are injured; but, the effect of what is being advocated is that foreign exporters, untrammeled as they are by any due process of law constraints, can injure the citizens of a State (domestic industry) through dumping so long as it is in the interest of the public at large or national economy, and get away with it, while, at the same time, as if to add insult to the injury, impose an additional burden on the State to do full cost-benefit analysis to allow for such a situation to develop. Due to the impracticality of following such a course for each and every AD action, it is hard to imagine any country doing such analysis. Even the $\mathrm{EU}^{59}$ and

56 Bentham took the idea of calculating pains and pleasures as a measure of utility from the Italian penal reformer Beccaria who in 1764 wrote: "Good legislation...is the art of conducting man to the maximum of happiness and to the minimum of misery, if we may apply this mathematical expression to the good and evil of life." Quoted in Stone, Julius. The Province and Function of Law. Law as Logic, Justice and Social Control. A Study in Jurisprudence at 272 (Sydney, 1946).

5T Stewart, Terence, "Administration of the Antidumping Law: A Different Perspective," in Boltuck and Litan, supra note 3,288 at 292.

58 In the case of the study carried out by USITC of the economic effects of existing AD and CVD orders and suspension agreements, four USITC Commissioners expressed doubts or reservations, to varying degree, as to the methodology followed. Economic Effects supra note 4, For the views of Commissioners Nuzum and Rohr, see, id. at VII. Commissioner Don Newquist felt that the report was essentially an academic exercise in modeling and counterfactual economic theory, id. at XI; Commissioner Bragg emphatically asserted that although "economic modelling is a useful tool, it cannot substitute for "real world' experience," id. at XIII.

59 Thakran, P.K.M. "Some Facets of Antidumping Policy: Summary of the Contents of the Volume" in Thakran, Policy, Implications of Antidumping Measures, supra note 28, at 7. 
Canada $^{60}$ which earlier followed a lesser test of "public interest" have veered away from it. It must be noted that despite the urgings from economists during the Uruguay Round, the URAA does not provide for a "public interest" clause and does not even include consumers, central to any national interest inquiry, among "interested parties" for purposes of $\mathrm{AD}$ investigations. ${ }^{61}$

\section{REMEDY AGAINST DUMPING: THE MUNICIPAL ANTIDUMPING LAWS}

Currently, more than 40 countries have enacted antidumping legislation. The antidumping actions originated first in Canada under an Act of $1904 .^{62}$ A novel measure in the form of antidumping duty was invented which was designed to satisfy manufacturers who desired higher customs duties and farmers whose interests lay in lower duties. ${ }^{63}$

Canada was followed by New Zealand (1905), Australia (1906) and South Africa (1914). In the U.S., the first antidumping legislation, the Revenue Act of $1916^{64}$ was enacted mainly out of concern for the protection of U.S. industry against the German cartels. From then onwards the history of antidumping is one of increased refinement and fine-tuning. With the passage of time, almost all the countries mentioned, including England, enacted new antidumping legislation.

The Revenue Act of 1916 of U.S. defined dumping as follows:

"It is unlawful to import articles into the United States at a price substantially less than the actual market value or wholesale price of such articles, provided that it was done with the intent to destroy or injure a United States industry or to prevent the establishment of such industry."

The "intent to destroy or injure" a U.S. industry was not easy to establish. The Antidumping Act of 1921, therefore, dropped this uncomfortable idea and instead provided:

\footnotetext{
${ }^{60}$ A writer has pointed at that "public interest" investigation led to a reduction in the level of duty in only one case. See Dutz, Mark A., "Enforcement of Canadian Trade Remedy Laws: The Competition Policies as an Antidote for Protection." in Finger, supra note 22, 203 at 215. It may also be noted that in Australia the inclusion of a "national interest" clause in the legislation was rejected because it would add to the uncertainty of the proceedings and administrative complexity and would increase cost of investigation to the parties and the Government. See Banks, Gary, "The Antidumping Experience of a GATT-Fearing Country" in id. 183, at 187.

61 Article $6 . \overline{6} .11$.

62 See An Act to Amend the Customs Tariffs of 1897, S.C. 1904, C 11, S. 19.

63 Earlier AD laws differ considerably with their recent counterparts. For example, up until 1969 Canadian legislation did not specify the requirement of injury test. See Magnus, Peter A, "The Canadian Antidumping System" in Jackson and Vermulst, supra note 45, 167 at 174.

64 Pub. L. No. 64-271, Section 801, 39 Stat. 798.
} 
"A special dumping duty will be applied upon a finding that a U.S. industry is being or is likely to be injured, or is prevented from being established, due to the importation of a class or kind of foreign merchandise that is being sold or is likely to be sold in the U.S. or elsewhere at less than its fair value." ${ }^{65}$

The U. S. law was amended ${ }^{66}$ to reflect the changes brought about by the Tokyo Round Antidumping Code. ${ }^{67}$ The law has further been amended in the light of the URAA. ${ }^{68}$

\section{ANTIDUMPING ON THE INTERNATIONAL PLANE AND VOICES OF CRITICISM}

Antidumping was not regulated under international law until the adoption of GATT 1947, although the League of Nations undertook a study of dumping as early as 1922. ${ }^{69}$ Article VI of GATT "condemned" dumping but did not outlaw it.

During the 1950's GATT faced only one challenge to antidumping. This was a complaint by Italy against Sweden's antidumping finding against Italian nylon stockings. ${ }^{70}$ Various aspects of antidumping, however, continued to engage the attention of GATT which had its groups of experts study them. ${ }^{71}$ It was, however, not until the Kennedy Round (1963) that the regulation of antidumping actions was taken up in earnest. At that time, considerable concern was expressed about the U.S. antidumping law and the manner of its application.

Despite some opposition an international code (GATT AD Code of 1968) on antidumping procedures was adopted ${ }^{72}$ but opposition thereto intensified in the U.S. Congress. The Code did, however, lead to major revisions of AD law of Canada and of the EU regulations. By the time of the Tokyo Round (1973), a number of issues in

65 Antidumping Act of 1921, Ch. 14 . 201-12, Pub. L. No 67-10, 42 Stat. 9, 11-15.

66 Anti-Dumping Act of 1921, as amended, 19 U.S.C. $\S 160$ et seq.

${ }^{67}$ See Agreement on Implementation of Article VI of the General Agreement on Tariff and Trade. GATT, The Texts of the Tokyo Round Agreements, at 127 et seq (Geneva, 1986).

68 Uruguay Round Agreements Act, Public Law 103-465 [H.R. 5110]; December 8, 1994. 108 STAT 4809. See also, Joint Report of the Committee on Finance, Committee on Agriculture, Nutrition, and Forestry and Committee on Governmental Affairs of the United States Senate to Accompany S. 2467 103D Congress, 2d Session, Report 103-412, November 22, 1994.

69 This endeavor resulted in Jacob Viner's study: Memorandum on Dumping. 3-19, L.N. Doc. C.E.C.P. 36(1), Sales No. 1926. II. 63 (1926).

70 See Swedish Anti-dumping Duties: Report Adopted on 26 February, 1955, BISD 35/81 in Prescatore, P., William J. Davey and Andreas F. Lowenfeld, Handbook of GATT Dispute Settlement, Release No. 4 Case 14 at [51] (New York, 1944).

71 See, GATT, Anti-dumping and Countervailing Duties, GATT Sales No. GATT/1958-2 11 (July 1958); Report adopted on 13 May 1959 (L/978), GATT, BISD 8 S/145 (1960); GATT, BISD 95/194 (1961).

${ }^{72}$ The Agreement was named "Agreement on the Implementation of Article VI of the General Agreement on Tariffs and Trade." It entered into force on July 1, 1968. For the text see, GATT, BISD 245/24 (1968). 
the implementation of the GATT AD Code of 1968 had arisen. These related to, among others: ${ }^{73}$

(i) the treatment of "sales at a loss" in home market for purposes of calculating domestic market price;

(ii) the allowances to be made to the domestic and export prices for purposes of their comparison;

(iii) the determination of material injury; ${ }^{74}$ and

(iv) the issue of standing, viz., who could initiate the $\mathrm{AD}$ investigations.

The Tokyo Round yielded a revised agreement on dumping (Tokyo Code). If the Tokyo Code resolved some issues, it gave rise to a whole host of other issues. During the 80s, the voices of dissatisfaction with $\mathrm{AD}$ laws and their application and the Tokyo Code rose in a mounting crescendo. Some writers instead of condemning dumping (as did Article VI of GATT 1947) instead began to condemn the AD measures. No where are such sentiments more forcefully articulated than in the writings of Michael Finger. Note some observations:

- - "Antidumping has been economic nonsense from its beginning, and it has become increasingly non-sensical over its eighty-seven-year life."

- - "Antidumping has long been part of the rhetoric of protection.

- Manipulation of customs valuation has long been part of the arsenal of antiimport weapons.

- $\quad$ - Antidumping is, in substance, another clever way to use customs valuation procedures as a weapon against imports.

- Antidumping preserves all the old tricks against reform of customs valuation, reforms that now constrain value for assessment of ad valorem customs duties to transactions value.

- Antidumping makes these tricks even more powerful. As increases of the 'dumping margin' they are fully added (100 percent rate) to import charges; as increases of the 'customs value' they would be added at the ad valorem tariff rate, which even in high-tariff countries is seldom as high as 100 percent." 75

- - "Dumping' became, in law as well as in practice, anything you could get the government to act against under the antidumping law." ${ }^{76}$

- - "Antidumping is not public policy, it is private policy. It is a harnessing of state power to serve a private interest: a means by which one competitor can

73 See Stewart, supra note 36, at 1439 et seq.

74 As one can imagine the issue of what is negligible and what is material remained unresolved. On the difficulty of defining "material", see Grey, Rodney De C., "Some Notes on Subsidies and the International Rules" in Wallace, supra note 39,61 at 69.

75 Finger, J. Michael, The Origins and Evolution of Antidumping Regulation, World Bank, Working Papers, WPS 783) at 23 (October, 1991).

${ }^{76}$ Id. at 28. 
use the power of the state to gain an edge over another competitor. . . antidumping is an instrument that one competitor can use against another -like advertising, product development, or price discounting. The only constraint is that the beneficiary interest must be a domestic one and the apparent victim a foreign one. ${ }^{77}$

- - "Antidumping is the fox put in charge of the henhouse: trade restrictions certified by GATT. The fox is clever enough not only to eat the hens, but also to convince the farmer that that is the way things ought to be. Antidumping is ordinary protection with a grand public relations program. ${ }^{, 78}$

Antidumping rules became one of the "central issues" at the Uruguay Round.79 Lack of agreement among countries on antidumping reforms even threatened the success of the Round. The new agreement, URAA, entered into force upon the establishment of WTO ${ }^{80}$ on January 1, 1995 and supersedes the Tokyo Code. ${ }^{81}$ Some salient features of the URAA may now be noted.

\section{URAA: THE NUTS AND BOLTS OF DUMPING ACTIONS}

\section{Determination of Dumping}

In defining what is dumping URAA follows the Tokyo Code. Thus a product is dumped if the export price is less than the "comparable price, in the ordinary course of trade, for the like product" in exporter's domestic market. If there are no sales of the like product in the domestic market in the ordinary course of trade or due to the market conditions or low volume of sales, such sales do not permit a proper comparison, comparison may be made with the export price to a third country or with the cost of production in the country of origin plus a reasonable amount for administrative, selling and general costs (ASGC) and for profits (constructed value). The basic idea here is the same as in the Tokyo Code which provided little guidance to the national implementing authorities in interpreting "ordinary course of trade", or in assessing low volume of domestic sales, or in determining when home market sales do not permit a proper comparison, or in case constructed value were used, in determining the reasonable amount of ASGC and profit. The practices followed by the International Trade Administration of the U.S. Department of Commerce (Commerce) on these matters came under strong criticism. ${ }^{82}$

77 Id. at 41.

78 Id. at 42 ; Finger, supra note 22, at 34 .

79 Financial Times, at 5 (July 10, 1990).

80 Article 18.4 .

81 There is no express provision repealing the Tokyo Code. However, Article 18.1 of URAA provides: "No specific action against dumping of exports from another member can be taken except in accordance with the provisions of GATT 1994, as interpreted by this Agreement." A footnote clarifies that this provision is not intended to preclude action under other provisions of GATT, as appropriate.

${ }^{82}$ Commerce's practices before the adoption of URAA could be summarized as follows: 
The URAA now clarifies that where sales constitute $5 \%$ or more of sales of the product in the importing country, such sales are considered sufficient for purposes of determining domestic market price. A lower ratio should also be acceptable where the evidence demonstrates that domestic sales at such lower ratios are nevertheless of such magnitude as to provide for a proper comparison. ${ }^{83}$

If the investigating authorities determine that the export price is higher than the domestic market price one would expect that the inquiry would end at this point. This, however, is not the case in practice as dumping may still be found in case the domestic market price is determined to be below the cost of production. The reason for this practice is that if the domestic market sales are below the cost of production then they might not be used for a fair value comparison. This approach can have two consequences. If the sales below cost are excluded, the weighted average of domestic price will be higher and may increase the possibility of a finding of dumping. Discarding such sales may also not leave enough sales above the cost of production to enable the authorities to determine the domestic sale price, thus making resort to constructed price inevitable with all its disadvantages for the exporter. The U.S. antidumping law provided for the exclusion of below-cost foreign market sales as a basis for determining domestic sale price if the sales were made over an extended period of time, in substantial quantities, and at prices that did not permit recovery of all costs within a reasonable period of time. Consequently, Commerce disregarded below cost sales if they constituted $10 \%$ or more of the sales under consideration. As regards interpreting "extended period of time" Commerce would generally disregard below-cost sales if these sales were made in three of six months. ${ }^{84}$

As regards the sales below cost, the URAA broadly reflects the U.S. antidumping law with some modifications (Article 2.2.1). It provides that if prices which are below per unit costs at the time of sale are above weighted average per unit

Continued

Volume of domestic sales: inadequate sales were defined as home market sales less than $5 \%$ of sales to third markets. 19 CFR Ch. III (4-1-90 Edition), \$353.49.

Ordinary course of trade: sale would not be in ordinary course of trade if they were below cost and would, therefore, be disregarded by Commerce in case they: (i) were made over an extended period of time and in substantial quantities and (ii) were not at prices which would permit recovery of all costs within a reasonable period. Id. $\$ 353.51$.

ASGC and profit: Commerce used a standard minimum of $10 \%$ of the cost for general expenses and $8 \%$ of the cost as minimum profit. According to Palmeter: “. . . these statutory amounts are not surrogates for data that are difficult to ascertain but are minimums to be used should the real amounts prove too low for the law's protectionist purposes." Palmeter, N. David, "The Antidumping Law: A Legal and Administrative Nontariff Barrier", in Boltuck and Litan, supra note 3,64 at 75.

83 Article 2, footnote 2 . This is clearly a positive achievement.

${ }^{84}$ About $60 \%$ of all antidumping cases decided in U.S. since 1980 are said to have been based in part on allegations of sales below cost. Cass, Ronald A. and Stephen J. Narkin. "Antidumping and Countervailing Duty Law: The United States and GATT" in Boltuck and Litan, supra note 3, 200 at 209. Horlick points out that below-cost sales "have become the centerpiece of U.S. antidumping law and policy - without any serious consideration being given to the phenomenon." Horlick in Jackson and Vermulst, supra note 45, at 133. 
costs for the period of investigation, such prices are to be considered to provide for the recovery of costs within a reasonable period of time. The URAA further clarifies that the extended period of time should normally be one year, but in no case less than six months. ${ }^{85}$ The URAA further clarifies when "sales below per unit costs" are construed to have been made in substantial quantities."

The URAA requires costs to be calculated on the basis of records kept by exporter under investigation if they are in accordance with the generally accepted accounting principles of the exporting countries and reasonably reflect the cost associated with production and sale of the product under consideration. ${ }^{87}$

There is also a provision about cost allocation. $\mathrm{AD}$ authorities shall consider evidence made available by exporter on cost allocation provided that such allocations have been historically utilized, in particular, in relation to amortization and depreciation periods and allowances for capital expenditures and other development costs. Adjustment in costs shall be made, among others, for circumstances in which costs during the period of investigations are affected by start-up operations. In this respect again URAA makes a significant improvement over the Tokyo Code. ${ }^{88}$

The use of arbitrary statutory minimum for ASGC and profits by national antidumping authorities in computing constructed domestic sale price will now no longer be possible under the URAA. ${ }^{89}$ Article 2.2.2 of URAA requires that ASGC and profits shall be based on actual data of the exporter or producer under investigation. If such a determination is not possible, resort may be had, as prescribed, to the amounts incurred or realized by exporter or producer in question for sales of the same general category of products, or the weighted average of amounts incurred or realized by other exporters under investigation for the domestic sale of like product. The authorities may use any other reasonable method also, but the amount of profits so established shall not exceed the profit normally realized by other exporters or producers on sales of product of the same general category in the domestic market.

\footnotetext{
85 Article 2 footnote 4.

86 Article 2 footnote 5 .

87 On accounting, Boltuck and Litan felt that respondent's task to comply with the information required by Commerce may be "complicated by the fact that foreign companies may use different accounting conventions than those required for data submission by the Commerce Department." See Boltuck, Richard and Robert E. Litan supra note 3,1 at 17.

${ }_{88}$ However, the failure of URAA to define start-up period has not gone unnoticed. See, Horlick, Gary N. and Eleanor C. Shea, "The World Trade Organization Antidumping Agreement" 29 J.W.T. 5 at 26 (1995, February).

89 See on this supra note 82 .
} 


\section{Export Price}

The export price may also be constructed where it appears to the $A D$ authorities that export price is unreliable because of association or a compensatory arrangement between exporter and importer or a third party. In such a case the basis for construction is the price at which imported products are first resold to an independent buyer, or if the product is not resold to an independent buyer or not resold in the condition as imported, on such reasonable basis as the $\mathrm{AD}$ authorities may determine.

\section{Adjustments}

The next step is the comparison to be made between the domestic price and the export price for determining the dumping margin. For this purpose it will be useful to keep the following equation in mind:

\section{Domestic Price}

or minus

Home Market Price
Export Price

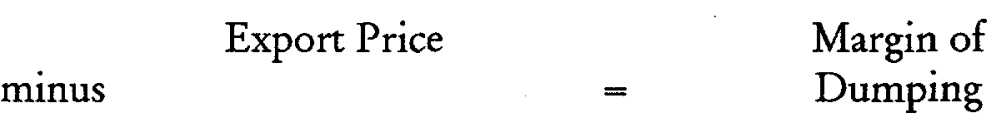

The URAA stipulates a "fair comparison" of the two prices. Surprisingly, the idea of "fair comparison" is not expressly stipulated in many national AD laws. If the "fair comparison" requirement is expressly provided for in the national legislation, it perhaps could, to some extent, check some of the abuses that take place in the comparison process.

A number of adjustments in these prices are allowed with the idea "to ensure that they are compared at proper level, that the comparison is one of apples to apples." $"$ The URAA provides some but not enough guidance in this respect. Thus it requires that comparison shall be made at the same level of trade, normally at exfactory level, and in respect of sales made at nearly the same time. Due allowance is made for differences that affect price comparability including, differences in conditions and terms of sale, taxation, levels of trade, quantities and physical characteristics.

With little to guide them except for the fair comparison standard which in turn is generally not even mentioned in the legislation, the municipal authorities, in making price adjustments, have adopted methodologies which stacked up the cards against the exporters. ${ }^{91}$

\footnotetext{
90 Palmeter, supra note 82 , at 76 .

91 On this see, Horlick, supra note 84 at 146; Palmeter, supra note 82 , at 76.
} 


\section{Comparison}

A significant improvement has been made by the URAA in the methodology for comparing the domestic sale price and the export price to determine the margin of dumping. The Agreement provides that the dumping margin is "normally" to be established by comparing weighted average of domestic price with weighted average of all comparable export prices or by comparison of prices on transaction - to transaction basis. Weighted average domestic sales prices may be compared with individual export transactions if authorities find a pattern of export prices which differ significantly among different purchasers, regions or times and if an explanation is provided why such differences cannot be taken into account in weighted-to-weighted or transaction-to-transaction comparison. ${ }^{92}$

\section{De Minimis Dumping Margin}

Article 5.8 of URAA requires the termination of antidumping investigations if dumping margins are found to be de minimis, which is defined as less than $2 \%$ of the export price. Also, investigation shall be immediately terminated where volume of dumped imports is negligible, i.e., if such volume from a particular country is less than $3 \%$ of imports in the country, unless countries which individually account for less than $3 \%$ of imports collectively account for more than $7 \%$ of imports of the like product. ${ }^{93}$ In this respect also the URAA makes a very positive advance.

\section{Determination of injury}

Mere existence of dumping is not sufficient for levying antidumping duty. Dumping must also result in material injury to domestic industry producing a like product.

The URAA requires injury determination to be based on positive evidence. This involves the examination of the volume of dumped imports and their effect on domestic prices of like product and the consequent impact of these imports on

92 The practice of comparing weighted average of domestic sale price with individual export prices followed by Commerce led to severest criticism and charge of protectionist bias. It was pointed out that even where both prices were identical but varying over a period of time, the comparison would yield a dumping margin in sales where the individual export price is lower than the weighted average of domestic sales price. Thus Palmeter observed:

"Average prices in both markets or average prices in neither. The present methodology of comparing individual export prices to weighted average home market (or third-country) prices is unfairness in its rankest form. It is perhaps the most blatant kind of deck-stacking that goes on in an antidumping proceeding. There is no justification for it." Id. at 85.

93 Prior to the entry into force of URAA, the practice of Commerce to treat dumping margin of less than $0.5 \%$ as de minimis thus allowing for imposition of antidumping duty where the dumping margin was $0.5 \%$ had been generally criticized. It had been unsuccessfully recommended that the U.S. raise the limit to $5 \%$. See Palmeter, id. at 87 . 
domestic producers. By injury is meant material injury to domestic industry, threat of material injury to a domestic industry or material retardation to establishment of a domestic industry. ${ }^{94}$ In examining the effect of such imports, the authorities must consider whether there has been a significant price-undercutting by dumped imports, or the prices are depressed significantly or price increases, which otherwise would have occurred, were prevented to a significant degree, or whether there has been a significant increase either in absolute terms or in relation to domestic production or consumption. For considering the impact on domestic industry, the factors to be considered are: actual and potential decline in output, sales, profits, market share, productivity, return on investments, or utilization of capacity; factors affecting domestic prices, magnitude of margin of dumping; actual and potential negative effects on cash flow, inventories, employment, wages, growth, and the ability to raise capital or investments. This list is not exhaustive and no one or several of these factors can necessarily give decisive guidance.

Notwithstanding the various tests prescribed in the URAA and the national $\mathrm{AD}$ statutes, the determination of what constitutes "material" remains a difficult issue. $^{95}$ It is, therefore, correctly maintained that despite "continuing improvements, the injury side of the Agreement remains far less developed than the dumping side. Basic injury-related concepts are not well-enough defined and the practicalities of the Contracting Parties differ greatly. The recent adoption of the Uruguay Round results will not really alter this situation.. ${ }^{96}$

\section{Cumulation}

The URAA also legitimizes the practice of cumulating imports from various countries for determining injury - a practice that developed in $\mathrm{EU}^{97}$ and the U.S. ${ }^{98}$ Cumulation, however, has always been unfair to small exporters whose exports would not have caused injury but for having been cumulated with exports of other exporters. But cumulation is not without some rationale. As Horlick points out:

\footnotetext{
94 In the U.S. the ITC considers 18 factors in determining material injury. See on this Boltuck, Richard "Assessing the Effects on the Domestic Industry of Price Dumping" in Tharakan, supra note 28, 99 at 114115. ITC commissioners have adopted 5 different approaches in reaching material injury determinations. See Kaplan, Seth "Injury and Causation in U.S. ITC Antidumping Determinations: Five Recent Approaches", id. 143 et seq.

${ }^{25}$ Horlick points that in the U.S. finding of injury will always be a matter of ITC discretion. "The greatest amount of legislative work, both internationally and in the U.S. on any single word in the antidumping law is the word 'material' preceding injury." Horlick, supra note 84, at 158 . On the subjective aspect of injury finding, see also Boltuck, Richard and Robert E. Litan, supra note 3 at 17.

96 Pangratis, Angelos and Edwin Vermulst, "Injury in Anti-Dumping Proceedings, The Need to Look Beyond the Uruguay Round Results", 28 J.W.T. 61 at 94 (1994, October).

97 Bellis, Jean François, "The EEC Antidumping System", in Jackson and Vermulst, supra note 45, at 9293.

98 Some doubt as to the consistency of the practice of cumulating imports with U.S. law was expressed by Horlick. See, Horlick, supra note 84, at 162.
} 
"[N]evertheless, there is an understandable view that being injured in many nibbles at once is just as bad as being injured in one large bite."

The URAA permits cumulation provided imports are simultaneously subject to investigations, the margin of dumping for each country is more than de minimis, the volume of imports is not negligible and a determination is made that cumulation of imports is appropriate in light of competition between imported products and of competition between imported products and like domestic products. ${ }^{100}$

\section{Causal Relationship}

There must be causal relationship between the injury and dumped imports. ${ }^{101}$ To the extent injury results from other factors such as the volume and prices of nondumped imports, contraction in demand or changes in the pattern of consumption, trade practices of, and competition between, the foreign and domestic producers, developments in technology, and the export performance and productivity of the domestic industry - such injury must be discounted from the determination of material injury. ${ }^{102}$

\section{Threat of Injury}

ADD may be imposed if dumping is causing material injury or threatens to cause material injury to domestic industry or materially retards ${ }^{103}$ the establishment of industry. Filing a complaint alleging a mere "threat" is full of difficulties and can easily, in turn, lead to abuse.

Article 3.7 of URAA stipulates that a threat of injury shall be based on facts and not merely on allegation, conjecture or remote possibility. The change in circumstances which would create a situation in which dumping would cause injury must be clearly foreseen and imminent. For example, if there is convincing reason to believe that there will be, in the immediate future, substantially increased imports of the product at dumped prices. Article 3.7 of URAA prescribes four factors as illustrative of what the authorities should consider to make a determination of the existence of a threat of material injury. These are:

${ }_{100}^{99} \frac{\text { Id. }}{\text { Articl }}$

Article 3.3

101 The URAA stipulates that it "must be demonstrated that the dumped imports are, through the effect of dumping . . causing injury ..."Article 3.5. In this respect, URAA mirrors the provision of the Tokyo Code. Horlick points out that causation is the "source of the most heated arguments in the antidumping area." Horlick, supra note 84 , at 161.

102 Perhaps, in this respect the most stringent text was contained in the GATT AD Code of 1968. It required that imports had to be "demonstrably the primary cause" of injury.

${ }_{103}$ What constitutes "material retardation" is not defined in URAA or municipal AD statutes. Allegations of material retardation of the establishment of an industry are not very common. See e.g., Benzyl Paraben from Japan, Inv. No. 731-Ta-462, (Final), USITIC Pub. 2355 (Feb. 1991). 
(a) a significant rate of increase of dumped imports indicating the likelihood of substantially increased importation;

(b) substantial increase in the capacity of the exporter indicating likelihood of substantially increased dumped exports to domestic markets taking into account availability of other export market to absorb additional exports;

(c) whether imports are entering at prices that will have a significant depressing or suppressing effect on domestic prices, and would increase demand for further imports; and

(d) inventories of the product being investigated.

The list of factors to be considered is not exhaustive consequently national laws may include other factors which are not mentioned in the URAA. As determination of threat is potentially a very controversial matter the URAA warns that in cases where injury is threatened by dumped imports, the application of antidumping measures shall be considered and decided with special care.

\section{Standing}

The URAA requires that an antidumping investigation may not be initiated unless the authorities have determined, on the basis of an examination of the degree of support for, or opposition to, the application, expressed by domestic producers of the like product, that the application has been filed "by or on behalf of the domestic industry." ${ }^{104}$

The application must be supported by domestic producers whose collective output constitutes more than $50 \%$ of the total production of the like product produced by that portion of the domestic industry expressing either support for or opposition to the application. No investigation shall be initiated if the proportion supporting the application produces less than $25 \%$ of the total production of the domestic industry. ${ }^{105}$ Producers who are themselves involved in the importing of the dumped products or are related to exporters or importers may be ignored. As a result of this provision, national authorities will have to seriously investigate that the petitioners have the required standing to complain. With increasing cross-border investments by multinationals a question arises whether a foreign multinational corporation operating

\footnotetext{
104 Article 5.4.

${ }^{105}$ Earlier on Commerce had taken the position that "standing exists for any petition filed unless a majority of the industry shows opposition." Thus where Commerce found standing "it had no idea what proportion of the domestic industry supported the petition." Horlick, supra note 84, at 154. Pursuant to the URAA, the U.S. AD law is amended requiring Commerce to poll the industry if the petition does not establish support of domestic producers or workers accounting for more than 50 percent of the total production of the domestic like product. 19 U.S.C. $1671 \mathrm{a}(\mathrm{c})(4)(\mathrm{D})$ and $1673 \mathrm{a}(\mathrm{c})(4)(\mathrm{D})$, as amended by Uruguay Round Agreements Act.
} 
in a country in which dumping is alleged would be considered a member of the domestic industry. The URAA does not throw much light on this issue. ${ }^{106}$

\section{Application for Investigation}

The URAA provides far more detailed rules as to the content of application for initiating the investigation than its predecessor the Tokyo Code. The application is required to include evidence of dumping, injury and causal link between dumped imports and alleged injury. Information to be provided in the application relates to: (a) the identity of applicant, volume and value of domestic production of like product by the applicant. If the application is made on behalf of the industry, applicant shall provide pertinent information relating to other producers; (b) complete description of dumped product, names of exporting countries, identity of known exporters or foreign producers, list of known importers of the product; (c) information on prices, inter alia, for which the product is sold in exporter's domestic market; and (d) information on evolution of volume of imports, effect of these imports in prices in domestic market and consequent impact of imports on domestic industry. Some other improvements made by URAA in this regard include:

1. The authorities shall examine the accuracy and adequacy of the evidence provided in the application to determine whether there is sufficient evidence to justify the initiation of an investigation.

2. The authorities shall avoid any publicizing of the application unless a decision has been made to initiate an investigation.

3. An application shall be rejected and an investigation terminated promptly if authorities concerned are satisfied that there is insufficient evidence of either dumping or injury. There shall be immediate termination where dumping margin is de minimis, or that the volume of dumped imports, actual or potential, or injury is negligible.

4. Only in special circumstances can investigations extend beyond one year and in no event beyond eighteen months after their initiation.

\footnotetext{
106 In U.S., ITC has developed a test to determine whether a petitioner has standing under the antidumping statute when it is challenged that the petitioner is not a domestic manufacturer. This test has the following six elements:

(1) the extent and source of a company's capital investment; (2) the technical expertise involved in the production activity in the United States; (3) the value-added to the product in the United States; (4) employment levels; (5) the quantity and types of parts sourced in the United States; and (6) any other costs and activities in the United States directly leading to production of the like product. Of course, no single element is determinative nor is the test exhaustive. See, Jerge, Martin "Foreign Multinational Corporations and U.S. Antidumping Law-Defining a Domestic Business", 28 J.W.T. 67 at 70 (1994).
} 


\section{Provisional Measures}

Once a preliminary affirmative decision has been made as to dumping and injury, and if in the judgment of the authorities it is necessary to prevent injury during the investigation period, provisional antidumping measures may be taken. Such measures may take the form of a provisional duty or preferably a security (by cash deposit or bond) equal to the amount of $\mathrm{ADD}$ provisionally calculated; withholding of appraisement is also recommended as an appropriate provisional measure. The URAA makes considerable improvement to the existing legal provisions by stipulating that no provisional measure shall be applied prior to 60 days after the initiation of investigation. ${ }^{107} \mathrm{~A}$ further improvement consists of the specific requirement that provisional measures shall be limited for as short a period as possible and in any case not to exceed 4 months, except upon request of exporters representing a significant percentage of the trade in which case the period shall not exceed six months. These time-limits may be extended to 6 and 9 months, respectively, in limited situations.

\section{Price Undertakings}

An alternative to antidumping duty which the URAA like its predecessor allows and which has been extensively used in the EU is the voluntary undertakings from the exporter. ${ }^{108}$ The authorities may suspend or terminate the proceedings if the exporter enters into voluntary undertakings to revise its price or to cease exports at dumped prices. It is desirable that price increases are less than the margin of dumping if they would be adequate to remove the injury, but they shall not be higher than necessary to eliminate the margin of dumping. Price undertakings shall not be sought before preliminary affirmative determination of dumping and injury. ${ }^{109}$

Authorities are not obligated to accept undertakings, if their acceptance is impractical, for example, if the number of actual or potential exporters is too great, or due to considerations of general policy or any other reason. ${ }^{110}$

After an undertaking has been accepted, the proceedings may be completed if the exporter so desires or the authorities so decide. If the result is that a negative

\footnotetext{
107 Article 7.3. This will dampen the ardor of protectionist interests who advocate imposition of provisional duties as early as possible. Earlier in Mexico a first provisional duty determination was permitted within 5 working days of the initiation of the investigation. This was followed by a second provisional duty and then a final duty. See on this Review of Trade and Investment Liberalization Measures by Mexico and Prospects for Future United States-Mexican Relations. Investigation No. 332282. Phase I: Recent Trade and Investment Reforms Undertaken by Mexico and Publications for the United States. USITC Pub. 2275 at 412 et seq. (1990).

108 In EU undertakings were initially quite popular but their exact details were not made public. See Bael, Ivo Van, "Ten Years of EEC Anti-Dumping Enforcement", 13 J.W.T.L. 395 (1979). For the reversal of the initial trend, see Bellis, supra note 97 at 52 et seq.

109 Article 8.2.

110 Article 8.3.
} 
finding of dumping or injury is made, the undertaking shall lapse. If, on the other hand, dumping and injury is found, the undertaking shall continue.

\section{Retroactivity}

The general rule, subject to some exceptions, is that (i) provisional measures shall only be applied to products which enter for consumption after the decision to apply such measures following investigation and preliminary affirmative determinations of dumping and injury enter into force; and (ii) ADD shall be applied to products which enter for consumption after the decision to apply the same enters into force. ${ }^{111} \mathrm{ADD}$ may be applied retroactively for the period for which the provisional measures applied in all those cases in which a final determination is made of injury (as distinguished from determination of threat of injury or material retardation of establishment of an industry $)^{112}$. The definitive ADD may be applied on imports entering not more than 90 days prior to date of application of provisional duty if authorities determine that there is history of dumping and the injury is caused by massive dumped imports in a relatively short time which will undermine the remedial effect of ADD. ${ }^{113}$ Retroactivity in no circumstance extends beyond the date of the initiation of the investigation and, therefore, the goods entering prior to such date will not be captured by the ADD. ${ }^{114}$

\section{Refund}

The URAA contains detailed rules applicable to the refund of duties. The practice as to refund has varied considerably in State practice and it had become almost impossible for an importer to get refund in the EU system. ${ }^{115}$ URAA requires that if the definitive $\mathrm{ADD}$ is lower than the provisional duty, the difference shall be reimbursed. ${ }^{116}$ Cash deposited during the application of provisional measures should be refunded in case the final determination is negative. ${ }^{117}$ Where the amount of antidumping duty is assessed on a retrospective basis, refund should be made within 90

111 Article 10.1.

112 Article 10.2.

113 Article 10.6. Bellis points out that although ADD has not been applied retroactively in the EU, there was a growing trend of complainants seeking such action. See Bellis, supra note 97, at 57 .

114 Article 10.8 .

115 See, however, McGovern who points out that it takes about three years to get refund. McGovern, Edmond, "EC Anti-dumping Legislation and Practices in Uruguay Round" (Further Papers on Selected Issues), U.N. Publication, Library call no. K 3943.A337 U78 (1990) 205 at 213. On EU practice, see also Rowat, Malcolm D., "Protectionist Tilts in Antidumping Legislation of Developed Countries and the LDC Response: Is the 'Race to the Bottom' Inevitable?", 24 J.W.T. offprint, at 9 (1990). See, generally, Vermulst, Edwin A., Antidumping Law and Practice in the United States and the European Communities, A Comparative Analysis at 252-254 (1987).

$\pi$ Article 10.3.

117 Article 10.5 . 
days from the determination of final liability. ${ }^{118}$ In case of prospective assessment of antidumping duty, refund of amount in excess of the actual dumping margin should normally take place within 12 months but not later than 18 months from the request for refund. The authorized refund should be made within 90 days of the decision. ${ }^{119}$ These provisions provide a much-needed discipline in the area of refund.

\section{Imposition and Collection of Antidumping Duty}

Under the URAA it is not mandatory to impose ADD where all conditions for imposition are met and it leaves the decision on the matter to the national authorities. The URAA states that it is desirable that the imposition be permissive by the Members and the duty be less than the margin if such lesser duty would be adequate to remove the injury to the domestic industry. ${ }^{120}$

The duty must be collected on a non-discriminatory basis from all sources found to be dumping and causing injury except from those whose price undertakings have been accepted. The suppliers subject to duty shall be named. In case a large number of suppliers is involved and it is not practical to name them then the exporting country may be named. If several suppliers from more than one country are involved then all suppliers may be named, and if that is impractical, all the supplying countries involved. ${ }^{12}$

In cases where some of several exporters are selected for examination, the duty shall not exceed the weighted average margin of dumping established with respect to selected exporters or producers. ${ }^{122}$

\section{New Exporters}

Under the EU system, exporters who enter the market after the imposition of the ADD are hit the hardest. Such exporters are required to pay the highest ADD imposed in the case. ${ }^{123}$ The situation is made worse in that the EU no longer accepts undertakings from exporters who did not export during the period of investigation. ${ }^{124}$ Article 9.5 of URAA stipulates that a prompt review shall be carried out for the

\footnotetext{
118 Article 9.3.1.

119 Article 9.3.2.

120 Article 9.1.

121 Article 9.2.

122 Article 9.4(i).

123 In the words of Piontek: “. . . individual rates of duty are usually determined by the Commission for each exporting company under investigation. The highest individual rate of duty imposed is also made the general rate, which applies to any exporter for which there is no individual rate of duty. Obviously, this can be very serious for a company which had no exports during the period being investigated, but which intends to export to the EEC subsequently." According to Piontek, this practice provides "overly protective edge" to the EU antidumping system. See, Piontek, supra note 38 , at 73 .

124 Sodium Carbonate, OJ (1984) L206/15 referred to in Bellis, supra note 97, at 56.
} 
purpose of determining individual margins of dumping for "any exporters or producers in the exporting country in question who have not exported the product to the importing member during the period of investigation." The burden is on such exporters to show that they are not related to those who are subject to the duty. This review is required to be conducted on an accelerated basis. No ADD shall be levied on such exporters during investigation. However, appraisement may be withheld or guarantees may be requested in such cases. The requirement to determine individual margin of dumping for new exporters provides a much-needed relief to such exporters.

\section{Duration of Antidumping Duties and Undertakings}

Up until 1984, the duration of ADD in EU and the U.S. was unlimited. In that year the "sunset" provision was introduced in the EU which provided that the duty and undertakings shall lapse after five years after the date on which they were introduced or last modified or confirmed. The practices of various countries varied considerably. ${ }^{125}$ Under Article 11 of URAA the general rule is that ADD shall remain in force only as long as and to the extent necessary to counteract dumping which is causing injury. The continuation of ADD may be reviewed by the authorities at any time at their own initiative or after a lapse of reasonable time, on the request of any interested party. If the review leads to a determination that the duty is no longer warranted, it shall be terminated forthwith.

The URAA establishes 5 years for the duration of ADD since its imposition or review unless before expiry of 5 years a review determines that expiry of antidumping duty would likely lead to continuation or recurrence of dumping and injury. ${ }^{126}$ Despite this possibility the establishment of 5 years as the maximum period ought to be recognized as a significant gain emerging from the Uruguay Round.

\section{Public Notice and Explanation of Determination}

The URAA has considerably strengthened the transparency of procedural requirements for antidumping cases. Thus it requires that Members the products of which are to be the subject of investigation as well as other interested parties must be notified and a public notice given when authorities have decided to initiate the proceedings. The public notice shall contain information as to:

(i) the name of the exporting country or countries;

(ii) the product involved;

(iii) the basis on which dumping is alleged;

125 Prior to the URAA, the periods for reviewing the continued need for the duty, were as follows: Australia, 2 years; Austria, 1 year; Canada, 5 years; EU, 5 years, U.S., no automatic time limit. With a view to bringing the U.S. law in line with URAA, Section 751 of the 1930 Tariff Act has been amended. The Amended Section 751(c) requires Commerce and ITC to conduct a "sunset" review every five years.

126 Article 11.3. 
(iv) the date of initiation of investigation;

(v) the summary of factors on which injury is alleged;

(vi) the address to which representations by interested parties should be directed; and

(vii) the time allowed to interested parties to making their views known. ${ }^{127}$

Public notice should also be given of all preliminary and final determinations as to dumping and injury, any decision to accept an undertaking and its termination and of the revocation of a determination. Each notice shall set forth or otherwise make available through a separate report sufficient details of the findings and conclusions reached on all material issues of fact and law. All such notices and reports are furnished to the Member the product of which is subject to investigation and the interested parties. Likewise, notices of provisional measures and of conclusion or suspension of an investigation as to definitive duty are also to be given. A public notice of the termination or suspension of an investigation following acceptance of an undertaking is to include the non-confidential part of the undertaking. ${ }^{128}$ This provision provides a much-needed transparency in this area.

\section{Judicial Review}

Members having antidumping legislation are required to maintain independent judicial, arbitral, administrative tribunals or procedures for, inter alia, the prompt review of administrative actions relating to final determinations and decisions of relating to the duration of $\mathrm{ADD}$ or undertakings. ${ }^{129}$ Availability of a review mechanism is unquestionably desirable for any system but it would appear to be particularly so for a system in which the determinations of dumping as well as of injury are made by a single entity.

\section{Best Information Available}

Annex II of the URAA is devoted entirely to the methodology involving the use of the "best information available" (BIA). To understand the nature of the issue, it should be noted that for making their determinations the investigative authorities issue a questionnaire to the exporters soon after the initiation of the investigation. ${ }^{130}$ But

127 Article 12.1.1.

128 Article 12.2.3.

129 Article 13.

130 In the U.S., a complaint has been that the questionnaire is too lengthy and cumbersome. Palmeter points out that the length of the first questionnaire given to foreign exporters in each of years 1987, 88, 89 and 90 was 52,73, 128 and 158 pages respectively. See Palmeter, supra note 82, at $64-65$. Not only is the questionnaire said to be complex, it seeks a lot of information on home market sales and sales to third countries. Commerce now requires response on computer tape in a specified format. Computerized sales are required to be submitted on eight-track computer tape in flat file or text format. "Computer tapes meeting the Department's requirements cannot be magically created from the company's existing recordkeeping system by simply pushing a button. The Company's raw data must be sorted, synthesized, and 
the national investigating authorities, such as the Commerce, may lack the subpoena powers for obtaining the necessary information. The U.S. law, therefore, provided for the use of "best information" to induce the exporters to provide accurate information. ${ }^{131}$ In the U.S., thus, if information cannot be verified or is submitted late or is in the wrong form, the exporter or manufacturer concerned will be notified and the Commerce will make its determination on the basis of BIA. If time permitted, Commerce could provide an opportunity to correct the information. However, it has been alleged that the demands being made are so onerous that more and more companies even of the stature of Matsushita, and Toshiba had failed to meet the burden of furnishing the information, ${ }^{132}$ thereby increasing resort by Commerce to BIA ${ }^{133}$ which at times is nothing more that the information furnished by the complainant. In the U.S., courts have generally upheld the use of BIA by Commerce. ${ }^{134}$ Due to the criticism that from the exporter's point of view BIA methodology often worked as the "worst information available", it was only appropriate that the issue were addressed by the URAA. Article 6(8) of the Tokyo Code recognized the use of BIA, but provided no further guidelines. The URAA, on the other hand, specifies various rules in that respect. The authorities may request information on a computer tape but not on a system other than the one used by the other party. The authority should not maintain a request for computerized response if the party concerned does not maintain computerized accounts and if presenting the requested information would result in unreasonable extra burden on it. If under these circumstances a party fails to provide computerized information, then, it should not be considered to significantly impede the investigation. URAA, Annex II, paragraph 5 may limit the wide discretion the national authorities had hitherto enjoyed of rejecting the information furnished by the exporters. Thus it is stipulated that even though the information provided may not be ideal in all respects, this should not justify the authorities from disregarding it, provided the interested party has acted to the best of its ability. Where the authorities rely on the information provided by the complainant, they should do so with "special

Continued

amended in order to meet DOC requirements and expectations." See Anderson, Charles L. and Thomas L. Rogers, "Preparing the Computerized Portions of an Antidumping Questionnaire Response," in Georgetown Univ. L. Center, The Annual International Trade Conference: The Litigation of an Antidumping Case. A Practitioner's Workshop 123 at 126 (June 4-5, 1992). Respondents may thus be subject to additional expense and inconvenience. Failure to provide information on tape was held to justify Commerce's resort to BIA. See Rhone Poulenc v. United States, 710 F. Supp. 341, at 346-47 (CIT 1989), Affirmed, 899 F.2d 1185 (Fed. Cir. 1990).

${ }_{131}$ Section 776 of the Tariff Act 1930 stipulated that if the Commerce is unable to verify the accuracy of the information submitted, it shall use the best information available to it as the basis for its actions which may include the information submitted by the complainant.

132 Palmeter, supra note 82, at 70.

133 See comments of Pietro S. Nivola in Boltuck and Litan, Down in the Dumps, supra note 3, at 280. Baldwin and Moore maintain that a dumping margin based on BIA is on average higher $(66.7 \%)$ than that based on the questionnaire of foreign firms (27.9\%). Baldwin, Robert E. and Michael O. Moore "Political Aspects of the Administration of the Trade Remedy Laws." See id. 253 at 269-70.

134 See Ansaldo Componenti, S.p.a. v United States 628 F. Supp. 198. (Commerce may refuse to consider information supplied after the time specified for submitting the information expires, and thus may use BIA.) Seattle Marine Fishing Supply Co. v United States, 679 F Supp. 1119 at 1127-28. (The CIT relying upon Ansaldo Componenti upheld Commerce's rejection of untimely questionnaire responses.) 
circumspection", and wherever practicable, check the information from independent sources. ${ }^{135}$

\section{Circumvention}

One of the problems with ADD on a product has been the circumvention of the duty by, inter alia, importing parts and reassembling the product in the importing country or by making minor alterations to the product subject to antidumping order. To prevent circumvention, $\mathrm{EU}^{136}$ was the first to make a legislative provision followed by the U.S. ${ }^{137}$ Anti-circumvention action, in effect, amounts to imposing ADD without investigation of dumping or injury. The "parts amendment" was challenged by Japan at the GATT as it was first invoked against Japanese companies with facilities in EU. A GATT panel found EU regulation violated Article III of GATT 1947. ${ }^{138}$ The EU did not block the adoption of the panel report but wanted its reconsideration. As expected, the circumvention problem was taken up at the Uruguay Round. However, due to lack of agreement the issue was deferred. At Marrakech the Ministers adopted a decision which acknowledged lack of agreement on the problem of circumvention and referred the matter to the Committee on Anti-Dumping Practices established under URAA for resolution as early as possible. ${ }^{139}$

\section{Anti-Dumping Committee}

Part II of the URAA establishes the Committee on Anti-Dumping Practices. Members are required to report without delay to the Committee all preliminary or final antidumping actions. This report will be open for inspection of government representatives. Members shall also submit, on a semi-annual basis, reports of antidumping actions taken within the preceding six months. Each Member must inform the Committee of its antidumping procedures as well as any changes in its antidumping laws and regulations as well as other relevant laws and procedures.

135 A new Section 782(e) has now been added to U.S. Tariff Act, 1930, requiring that Commerce and ITC may not decline to consider information which does not meet all the requirements established therefor if: (i) the information is submitted within the established deadline, (ii) it can be verified to the extent required by law, (iii) it is not so incomplete that it cannot serve as a reliable basis for reaching the required determination, (iv) the respondent has demonstrated that it has acted to the best of its ability in providing the information and meeting the requirements, and (v) it can be used without undue difficulties.

136 Council Regulation No. $1761 / 87$ of June 1987 amending Regulation No. 2176/84 of 23 July 1984 ("parts amendment"). Prior to URAA the provision appeared as Article 13(10) of Council Regulation No. 2423/88 of 11 July 1988.

137 Tariff Act of 1930. $\S 781$ as amended by the Omnibus Trade and Competitiveness Act of 1988, Pub. L. No. 100-418 §1321, 102 Stat $1107,1192-95$. Section 781 has been further amended although no definitive agreement on anticircumvention was reached at the Uruguay Round.

138 EEC - Regulation on Imports of Parts and Components, Report by the Panel, GATT Doc. No. L/6657 at 66 et seq (March 22, 1990).

139 A view has been expressed that if the matter is not resolved in the near future, it might encourage unilateral adoption of anti-circumvention provisions. McNamara, Tim and Edwin Vermulst, "Special Trade Law Issues in the EC for Assembly Products", 28 J.W.T. 83 at 100 (1994). 


\section{Dispute Settlement}

The dispute settlement mechanism of GATT 1947 has often been criticized. ${ }^{140}$ The report of a panel set up by the GATT CONTRACTING PARTIES in respect of a dispute could be blocked from being adopted by any Contracting Party to the dispute. In the case of antidumping, out of 5 cases in which panels submitted their reports only in 2 was the report adopted. Some pessimism about the effectiveness of dispute settlement mechanism in relation to challenges to antidumping measures stems from the reports in two recent cases in which the panels while holding the antidumping measures inconsistent with the Tokyo Code nonetheless did not revoke the duty. ${ }^{141}$ Finger and Fung say:

"The conclusion is obvious - and ominous. The GATT dispute settlement process seems unlikely to provide discipline against the increasing number of antidumping restrictions against imports. Both the bureaucratic and the legal momentum of GATT dispute settlement are toward innocuous findings of procedural error that can be corrected without lifting the antidumping order in question.

Changing the bureaucratic momentum of the system is possible, but it would not be easy. Changing the legal momentum of the system will be even more difficult. Interpreting the GATT in a legalistic way compels one to interpret it as a statement of rights to impose antidumping duties. The substantive criteria for action are broad - the injury concept justifies protection for anyone to whom it is worth the time to ask for it. The constraints on antidumping actions are artificial loopholes and procedural technicalities - so legal reform means getting rid of them.

In sum, where do the GATT articles on trade remedies lead us? If you take a legalistic view, you come to a protectionist conclusion." ${ }^{142}$

A closer examination of the two panel reports which seem to have driven the two writers to the view that the panels would lean toward innocuous findings of procedural errors that can be corrected rather than lift the challenged antidumping

140 Hilf, Meinhard, "Settlement of Disputes in International Economic Organizations: Comparative Analysis and Proposals for Strengthening the GATT Dispute Settlement Procedures" in Petersmann, ErnstUlrich and Meinhard Hilf, The New GATT Round of Multilateral Trade Negotiations, Legal and Economic Problems, 285 at 300-1 (1991).

141 See Finger, J. Michael and Kwok-Chiu Fung, "Will GATT Enforcement Control Antidumping?" 9 Jn'l Econo. Integration, 198 (1994). The authors pointedly refer to the GATT Panel Reports in United States - Salmon from Norway (1992) and Korea - Polyacetyl Resins from the United States (1993), at 204. ${ }^{142}$ Id. at 211 . 
measure, would show that the panel recommendations were appropriate, and, in the circumstances, at least in one case, in accordance with the complainant's request.

In U.S.- Salmon from Norway ${ }^{143}$, the Panel found U.S. antidumping actions inconsistent with the Tokyo Code as regards: "the calculation of the cost of production in the country of origin"; attribution to one of the Norwegian farms the highest cost of production figure calculated on the basis of BIA without considering how this would affect the representativeness of the sample; and absence of proper consideration of differences in weight categories as a factor "which possibly affected" the comparability between constructed normal value and export prices. ${ }^{144}$ The Panel rejected Norwegian contentions on all other points. Would it have been appropriate for the Panel to recommend revocation of U.S. antidumping duty for certain incorrect aspects of methodology followed by U.S. authorities? Here is what the Panel says:

". . . the Panel took into account that the ground upon which it had found that the United States had imposed anti-dumping duties inconsistently with its obligations under the Agreement pertained specifically to certain aspects of the methodology for calculating margins of dumping. It could not be presumed that a methodology of calculating dumping margins consistent with the Panel's findings on these aspects would necessarily result in a determination that no dumping existed rather than in a determination that duties were to be imposed at a different rate. The Panel therefore found that in this situation it could not recommend that the Committee request the United States to revoke the ADD order and reimburse any duties paid or deposited under this order, as requested by Norway." 145

The Panel, therefore, recommended to the Antidumping Committee to request that the U.S. bring its measures into conformity with its obligations under the Tokyo Code, and that, to this end, the U.S. reconsider the affirmative final determination of dumping, consistent with the Panel's findings and take such measures with respect to its $\mathrm{ADD}$ order, as may be warranted in the light of that reconsideration. ${ }^{146}$

In Korea-Polyacetil Raisins from the United States, ${ }^{147}$ U.S. itself had requested the Panel to recommend that the Committee on Anti-Dumping Practices request Korea "to bring its law as applied into conformity with its obligations under the Agreement" and no revocation of the duty was expressly sought. Due to the vagueness of U.S. request, the Panel ruled that Korea "bring its measure (the imposition of antidumping duties . . . into conformity with its obligations under the Agreement)" 148

\footnotetext{
143 GATT ADP/87, 30 November 1992.

144 Id. at 217.

145 Id. at 218 .

$146 \overline{\text { Id. }}$.

147 Pescatore, Pierre, William J. Davey and Andreas F. Lowenfeld, Handbook of GATT Dispute Settlement, 693 (Deventer, 1994).

148 Id. at 731.
} 
There was nothing to prevent the U.S., if it so desired, to request the revocation of the duty. It will also be noted that in both cases the Panels left the door open for revocation of the duty. Be this as it may, it must be pointed out that although the dispute settlement mechanism agreed at the Uruguay Round is a considerable improvement over that of GATT 1947, so long as the national authorities do their homework objectively and correctly, it is not very likely that their decisions would be upturned. Thus, the URAA provides:

"(i) in its assessment of the facts of the matter, the panel shall determine whether the authorities' establishment of the facts was proper and whether their evaluation of those facts was unbiased and objective. If the establishment of the facts was proper and the evaluation was unbiased and objective, even though the panel might have reached a different conclusion, the evaluation shall not be overturned;

(ii) the panel shall interpret the relevant provisions of the Agreement in accordance with customary rules of interpretation of public international law. Where the panel finds that a relevant provision of the Agreement admits of more than one permissible interpretation, the panel shall find the authorities' measure to be in conformity with the Agreement if it rests upon one of those permissible interpretations." 149

\section{CONCLUSION}

The alarming increase in the number of antidumping actions pursued by the developed and developing countries has caused considerable concern among economists and trade reformers. These concerns have led to the suggestions of substituting antitrust principles for antidumping laws and regulations or for using safeguard measures under Article XIX of GATT 1994 and the URSA. At the current stage of the development of international trade law neither proposal appears feasible. Moreover, antidumping actions have become a fact of life and the international community recognizes such actions as the only legitimate tool to combat dumping as defined by and determined in accordance with law. Despite the urgings in some quarters neither municipal legal systems nor international agreements have mandated an "economy-wide" cost-benefit analysis of proposed antidumping actions. Due to political, technical and other implications, the acceptance of such a methodology in the near future is unlikely. The URAA has enhanced the discipline and made a number of improvements, although it cannot claim to have plugged all loopholes for the misuse of antidumping. In those matters where URAA is silent, ambiguous or provides room for flexibility in adopting a rule, national authorities should adopt a less trade restrictive rule or practice. A case in point is the U.S. practice relating to voting in the

149 Article 17.6. 
ITC. A 3-3 vote in AD and CVD investigations constitutes an affirmative decision. ${ }^{150}$ It will be preferable to require a clear majority rather than to treat an evenly divided vote as sufficient to establish a finding of injury.

The URAA in conjunction with the Dispute Settlement Mechanism of the WTO is expected to further curb the proliferation and misuse of antidumping. Thus, a U.S. business executive, Intel's Maibach, is quoted as observing:

"Almost every step of the procedure is going to be more difficult for United States petitioners...

Higher requirements for information will make it more difficult to file complaints... Proving injury will be harder because of changes in standards that relate to proof of injury... Proving the actual size of dumping margins will also be more difficult because of technical changes affecting how profits are calculated and other factors... Cases will also be likely to end up before a World Trade Organization panel, which may have judges that are less sympathetic, and possibly less objective, in interpreting dumping laws..." 15

iso 19 U.S.C. $1677(11)$

$151 \quad 13$ I.T.R. at $328(1996)$. 


\begin{tabular}{|c|c|c|c|c|}
\hline & Title & Author & Date & $\begin{array}{l}\text { Contract } \\
\text { for paper }\end{array}$ \\
\hline WPS1801 & Regional Integration as Diplomacy & $\begin{array}{l}\text { Maurice Schiff } \\
\text { L. Alan Winters }\end{array}$ & August 1997 & $\begin{array}{l}\text { J. Ngaine } \\
37947\end{array}$ \\
\hline WPS1802 & $\begin{array}{l}\text { Are There Synergies Between } \\
\text { World Bank Partial Credit } \\
\text { Guarantees and Private Lending? }\end{array}$ & Harry Huizinga & August 1997 & $\begin{array}{l}\text { P. Sintim-Aboagye } \\
38526\end{array}$ \\
\hline WPS1803 & $\begin{array}{l}\text { Fiscal Adjustments in Transition } \\
\text { Economies: Social Transfers and the } \\
\text { Efficiency of Public Spending: A } \\
\text { Comparison with OECD Countries }\end{array}$ & $\begin{array}{l}\text { Barbara Fakin } \\
\text { Alain de Crombrugghe }\end{array}$ & August 1997 & $\begin{array}{l}\text { M. Jandu } \\
33103\end{array}$ \\
\hline WPS1804 & $\begin{array}{l}\text { Financial Sector Adjustment Lending: } \\
\text { A Mid-Course Analysis }\end{array}$ & Robert i. Cull & August 1997 & $\begin{array}{l}\text { P. Sintim-Aboagye } \\
37644\end{array}$ \\
\hline WPS1805 & $\begin{array}{l}\text { Regional Economic Integration and } \\
\text { Agricultural Trade }\end{array}$ & Junichi Goto & August 1997 & $\begin{array}{l}\text { G. llogon } \\
33732\end{array}$ \\
\hline WPS 1806 & $\begin{array}{l}\text { An International Statistical Survey } \\
\text { of Government Employment and } \\
\text { Wages }\end{array}$ & $\begin{array}{l}\text { Salvatore Schiavo-Campo } \\
\text { Giulio de Tommaso } \\
\text { Amitabah Mukherjee }\end{array}$ & August 1997 & $\begin{array}{l}\text { M. Guevara } \\
32959\end{array}$ \\
\hline WPS1807 & $\begin{array}{l}\text { The Ghosts of Financing Gap: } \\
\text { How the Harrod-Domar Growth } \\
\text { Model Still Haunts Development } \\
\text { Economics }\end{array}$ & William Easterly & August 1997 & $\begin{array}{l}\text { K. Labrie } \\
31001\end{array}$ \\
\hline WPS1808 & $\begin{array}{l}\text { Economic Transition and the } \\
\text { Distributions of income and Wealth }\end{array}$ & Francisco H. G. Ferreira & August 1997 & $\begin{array}{l}\text { M. Geller } \\
31393\end{array}$ \\
\hline WPS1809 & $\begin{array}{l}\text { Institutions in Transition: Reliability } \\
\text { of Rules and Economic Performance } \\
\text { in Former Socialist Countries }\end{array}$ & $\begin{array}{l}\text { Aymo Brunetti } \\
\text { Gregory Kisunko } \\
\text { Beatrice Weder }\end{array}$ & August 1997 & $\begin{array}{l}\text { M. Geller } \\
34393\end{array}$ \\
\hline WPS1810 & $\begin{array}{l}\text { Inspections and Emissions in India: } \\
\text { Puzzling Survey Evidence about }\end{array}$ & $\begin{array}{l}\text { Sheoli Pargal } \\
\text { Muthukumara Mani } \\
\text { Mainul Huq }\end{array}$ & August 1997 & $\begin{array}{l}\text { E. Krapf } \\
80513\end{array}$ \\
\hline WPS1811 & $\begin{array}{l}\text { Agricultural Development: Issues, } \\
\text { Evidence, and Consequences }\end{array}$ & $\begin{array}{l}\text { Yair Mundak } \\
\text { Donald F. Larson } \\
\text { A Crego }\end{array}$ & August 1997 & $\begin{array}{l}\text { P. Kokila } \\
33716\end{array}$ \\
\hline WPS 1812 & $\begin{array}{l}\text { Managing Guarantee programs in } \\
\text { Support of Infrastructure Investment }\end{array}$ & Michael Klein & August 1997 & $\begin{array}{l}\text { S. Vivas } \\
82809\end{array}$ \\
\hline WPS1813 & Tackling Health Transition in China & Shaikh l. Hossain & Augusi 1997 & $\begin{array}{l}\text { C. Anbiah } \\
81275\end{array}$ \\
\hline WPS1814 & $\begin{array}{l}\text { Making Education in China Equitable } \\
\text { and Efficient }\end{array}$ & Shakh l. Hossain & August 1987 & $\begin{array}{l}\text { C. Anbiah } \\
81275\end{array}$ \\
\hline
\end{tabular}




\section{Policy Research Working Paper Series}

Title

WPS1815 Uniair Trade? Empirical Evidence in Worid Commodity Markets Over the Past 25 Years

WPS1816 Returns to Regionalism: An Evaluation of Nontraditional Gains from Regional Trade Agreements

WPS1817 Should Core Labor Standards Be Imposed through International Trade Policy?

WPS1818 What Affects the Russian Regional Governments' Propensity to Subsidize?

WPS1819 The Argentine Pension Reform and Its Relevance for Eastern Europe

WPS1820 Private Pension Funds in Argentina's New integrated Pension System

WPS1821 The "IPO-Plus": A New Approach to Privatization

WPS1822 intergovernmental Fiscal Transfers in Nine Countries: Lessons for Developing Countries
Author

Jacques Morisset

Raquel Fernandez

Keith E. Maskus

Lev Freinkman

Michael Haney

Dimitri Vittas

Dimitri Vittas

Itzhak Goldberg

Gregory Jedrzejczak

Michael Fuchs

jun Ma
September 1997

Contact

for paper

August 1997

N. Busjeet 33997

August 1997

I. Ngaine 37947

August 1997

J. Ngaine 37947

August 1997

N. Campos 38541

August 1997

P. Infante 37642

August 1997

$P$. infante 37642

August 1997

1. Goldbers 36289

C. Ima 35856 